DIW BERLIN

Discussion

Papers

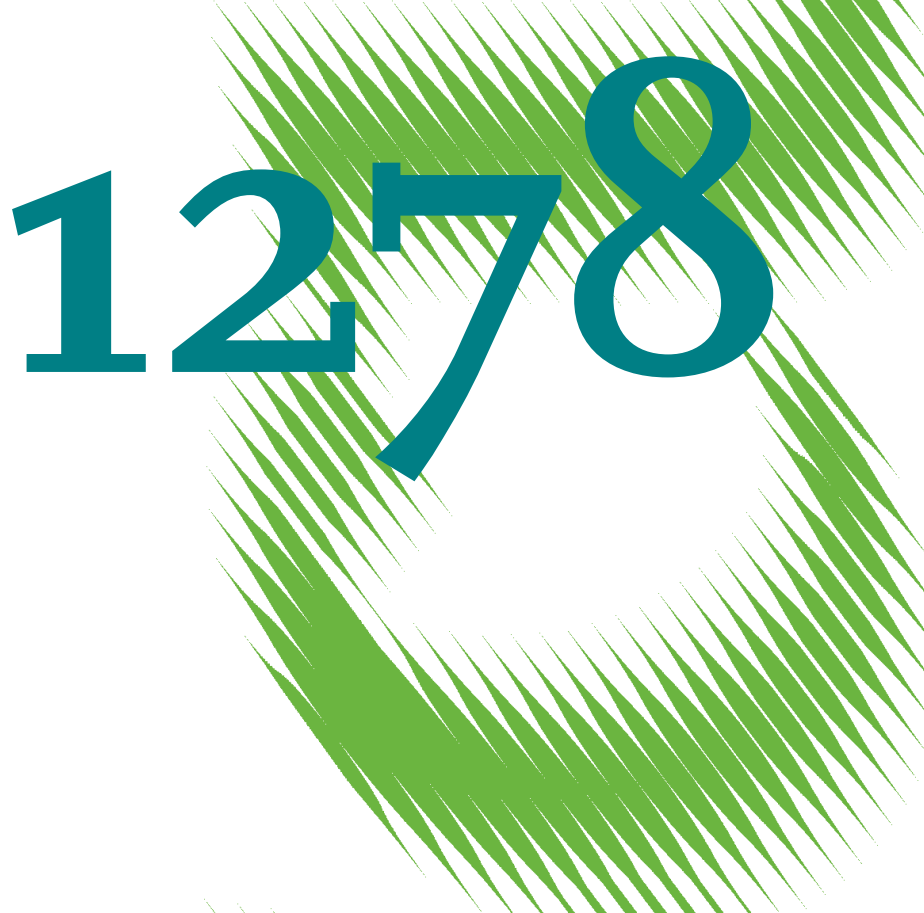

Is the Willingness to Take Financial Risk a Sex-Linked Trait?

Evidence from National Surveys of Household Finance 
Opinions expressed in this paper are those of the author(s) and do not necessarily reflect views of the institute.

IMPRESSUM

(C) DIW Berlin, 2013

DIW Berlin

German Institute for Economic Research

Mohrenstr. 58

10117 Berlin

Tel. $+49(30) 89789-0$

Fax +49 (30) $89789-200$

http://www.diw.de

ISSN print edition $1433-0210$

ISSN electronic edition 1619-4535

Papers can be downloaded free of charge from the DIW Berlin website:

http://www.diw.de/discussionpapers

Discussion Papers of DIW Berlin are indexed in RePEc and SSRN:

http://ideas.repec.org/s/diw/diwwpp.html

http://www.ssrn.com/link/DIW-Berlin-German-Inst-Econ-Res.html 


\title{
Is the willingness to take financial risk a sex-linked trait? Evidence from national surveys of household finance*
}

\author{
Nataliya Barasinska \\ (Deutsche Bundesbank) \\ Dorothea Schäfer \\ (DIW Berlin and Jönköping International Business School)
}

\begin{abstract}
We investigate whether the willingness to take investment risk is a sex-linked trait and link the results to the country's gender equality regime. Our empirical analysis involves household data on financial asset holdings as well as on self-reported risk tolerance for Austria, Italy, the Netherlands and Spain. Of those countries, Italy is by far the country with the greatest degree of gender inequality according to the 2009 Global Gender Gap Report. Two stages of building a portfolio of financial assets are analyzed. For the first-stage decision of whether to invest in risky assets in the first place, gender is found to have no effect in Austria, the Netherlands and Spain but does have an impact in Italy. However, even for Italy, it seems to be irrelevant in the second-stage decision about the share of wealth invested in the risky assets. We infer from these findings that, for countries with a high degree of gender equality, it is inappropriate to base financial advice primarily on gender.
\end{abstract}

Keywords: gender, risk aversion, financial behavior.

JEL classification: G11, J16.

\footnotetext{
*Nataliya Barasinska. Contact address: Deutsche Bundesbank, Wilhelm-Epstein-Str. 14, 60431 Frankfurt/Main, Germany. Phone: +49 699566 5113. E-Mail: nataliya.barasinska@bundesbank.de. Dorothea Schäfer. Corresponding author. Contact address: DIW Berlin, Mohrenstr. 58, 10117 Berlin, Germany. Phone: +49 3089789 162. E-Mail: dschaefer@diw.de The authors would like to thank to Heinz Hermann, Tobias Schmidt and participants of the research seminar at the Deutsche Bundesbank. The valuable input by Oleg Badunenko at the early stages of this study and the excellent research assistance provided by Michael Viertel are also gratefully acknowledged. The authors would furthermore like to thank Dimitris Georgarakos, Reinhard Hujer, Alexander Muravyev and Alfred Steinherr for their helpful comments and suggestions. The work is part of the FINESS project (Financial Systems and Stimulation of Sustainable Growth, work package Gender and Capital Markets) supported by the European Commission (7th Framework Programme, Grant Agreement No. 217266). Discussion Papers represent the authors' personal opinions and do not necessarily reflect the views of the Deutsche Bundesbank or its staff.
} 


\section{Introduction}

It is commonly believed that the willingness to take risk in investment decisions is a sexlinked trait. Men are, in general, considered to be more willing to take risks than women. Against this backdrop, the financial industry tends to take gender as a proxy measure for the willingness to invest in risky assets. Financial advice often differs for men and women, and some banks and insurance companies even design gender-specific financial products. ${ }^{1}$ This paper is the first to investigate whether the simplistic approach of taking gender as a proxy measure for the readiness to invest in risky assets is valid across countries with distinct gender equality levels.

An analysis of gender effects on the investment decisions requires a multi-country framework, as social norms are an important determinant of gender differences in economic behavior. Social norms that prescribe which behavioral patterns are appropriate for men and women may explain why women are more risk-averse than men. In the social identity framework of Akerlof and Kranton (2000), it can be optimal for a woman (man) to act more (less) risk-averse than she (he) actually is if the social norm prescribes that financial risk-taking is a male domain. Based on this framework, we argue that social norms can determine whether men and women make financial decisions in accordance with their risk preferences or not. Specifically, we hypothesize that in societies with traditionally distinct gender roles, men and women with equal risk preferences may nonetheless differ in their actual risk-taking. If this conjecture is true, gender can improve the predictive power of a model that links investment behavior to the self-reported risk preferences only. In societies with high gender equality, however, men and women should act in line with their individual risk preferences. In this case, investors' individual risk preferences and not gender will be a good predictor of risk-taking.

Our empirical test of the predictive power of gender for the actual risk taking is based on household survey data from Austria, Italy, the Netherlands and Spain. ${ }^{2}$ These are the only countries for which detailed data on both of the pieces of information - financial asset holdings of households and subjective risk preferences of household members - are available. Furthermore, according to the Global Gender Gap Report, these four European countries differ notably in the degree of gender equality. ${ }^{3}$ In particular, in 2006 Italy was the least gender-egalitarian of the four countries under review.

The extent of risk taken by investors is measured along two dimensions. The first one regards the decision on whether to include risky financial assets in the portfolio or not (participation decision). The second dimension of financial risk-taking is related to the decision about the share of the financial portfolio allocated to risky assets (allocation decision). Risky assets in our application are defined as directly held stocks and, later in a robustness check, as directly held stocks plus mutual funds. A similar approach to the measurement of financial risk taken has been applied in previous empirical studies of financial risk-taking, in particular, Jianakoplos and Bernasek (1998), Bajtelsmit,

\footnotetext{
${ }^{1}$ See, for example, a recent advertising campaign by the German insurer ERGO group which sells different insurance products to men and women, Handelsblatt No 250, December 27, 2011, page 32.

${ }^{2}$ Austrian Survey of Household Financial Wealth 2004; Italian Survey of Household Income and Wealth (SHIW) Wave 2004; Spanish Survey of Household Finances (EFF) Wave 2005; DNB Household Survey Wave 2004.

${ }^{3}$ http://www.weforum.org/pdf/gendergap/report2009.pdf.
} 
Bernasek, and Jianakoplos (1999), and Bernasek and Shwiff (2001). However, we depart from these studies in an important way. We set up an empirical framework that allows us to discriminate between the gross impact of gender (i.e. when individual risk preferences are not taken into account) and the incremental impact of gender (i.e. when risk preferences are controlled for). The formal test of the impact relies on the econometric analysis. The effect of gender on the participation decision is estimated using a probit regression model. While analyzing the allocation decision, we use the Heckman two-stage estimation procedure to account for a potential sample selection bias which is likely to emerge when the two portfolio decisions - investing in risky assets and the size of the investment - are correlated through common factors.

Our results confirm most of our expectations. For the participation decision, we find indeed that the predictive power of gender for taking investment risk varies across countries. In the three countries with relatively high gender equality, men and women who report equal risk preferences are equally likely to hold risky financial assets in their portfolios, ceteris paribus. The insignificance of the gender effect in those countries refutes the belief that gender is a good predictor of financial risk-taking. The self-reported risk tolerance provides the correct information about the individual's readiness to invest in risky assets, but gender does not. In Italy, the country with the greatest gender inequality among the four countries in our study, women are less likely to hold risky assets than men, even if they report equal degrees of risk tolerance. Thus, in this country, in addition to risk preferences gender seems to have an incremental effect on the actual risk-taking behavior. A slightly different finding emerges for the second stage of the decision-making process, the allocation decision. In all countries - even Italy - gender has no effect on the share of the wealth that is allocated to risky assets when risk preferences are taken into account.

We also take advantage of the richness of the data collected by the Dutch survey and investigate the role of gender in households with different structures of financial decisionmaking. In particular, we distinguish between two groups of couples: those with a clear division of financial decision-making and those where no such division exists. The first group comprises couples where each partner manages his/her own finances individually and couples where the entire financial resources are managed by one of the partners. The second group consists of households where both spouses are equally involved in the financial management. This group constitutes $2 / 3$ of all couples in our sample. We then investigate the role of gender in those two groups separately. For the first group (couples with a clear division of decision-making), we obtain the same results on the role of gender as we did for the whole Dutch sample. For the second group (couples with mutual decision-making), the results are different and worth mentioning in more detail. Specifically, we find that the risk preferences of both spouses have a significant effect on the risk-taking of the couple. Moreover, if spouses have different risk preferences, this results in a compromise with respect to risk-taking. In particular, at any given level of risk tolerance of one partner, having a more risk-averse spouse reduces the probability that the couple holds risky assets. This result is important with regard to any research involving household data. Any prediction with respect to financial risk-taking by couples with mutual decision-making must take into account the preferences of both partners. This finding holds not only for financial risk-taking but also for other economic decisions. In contrast to risk preferences, the gender of neither of the spouses provides information about the risk-taking by couples with mutual decision-making. Although no hard facts 
exist, we can with a fair degree of certainty argue that such couples make a large portion of the households in the population. Therefore, gender seems to be an irrelevant factor for the financial risk-taking in a large proportion of the population.

To sum up, our results show that it is inappropriate to base financial advice merely on the gender of investors. This holds in particular for countries with high gender equality and in general for financial advice to married couples. Advice that infers the risk propensity of an investor from gender only may lead to suboptimal investment decisions. These findings contribute to a number of research areas: the research on the link between gender and risk attitude, the stream of literature on the role of cultural determinants in the financial behavior of men and women, the research on household finance and also the research on financial advice (see e.g. Hackethal, Haliassos, and Jappelli, 2012).

The remainder of the paper is organized as follows. In the next section, we review the literature investigating gender-specific behavior in financial risk-taking. In Section 3 , we formulate our research hypothesis and provide its theoretical foundation rooted in the social identity framework of Akerlof and Kranton (2000). Section 4 gives a detailed overview of the empirical approach to the hypothesis testing. Here, we describe our data (4.1), comment on the measurement of gender equality in the countries studied (4.2) and explain how we measure the extent of risk actually taken by investors (4.3) and their risk preferences (4.4). The econometric model is presented in Section 5. In Section 6, we report the results regarding the gender effect on two types of investment decisions: ownership of risky assets and allocation of wealth to these assets. In Section 7, we check how robust the results are with respect to different sample cuts and a different definition of risky assets. Section 8 concludes.

\section{What does the literature say about the role of gen- der in risk-taking?}

Numerous papers studying the financial behavior of individuals find significant gender differences in risk-taking. For instance, portfolios of financial assets held by women seem to be generally less risky than portfolios held by men (Jianakoplos and Bernasek, 1998; Bajtelsmit et al., 1999; Bernasek and Shwiff, 2001). Recently, Beckmann and Menkhoff (2008) find a similar relationship in the behavior of professional investment fund managers. Furthermore, a number of experimental papers document systematic differences between men and women with respect to choices of risky gambles; see Croson and Gneezy (2009) and Eckel and Grossman (2008) for a comprehensive review of this literature. The findings of these studies convey a broadly uniform message that women are less willing to take financial risk than men.

Yet, a growing number of studies put the previous findings into perspective or refute them altogether. In particular, Schubert, Brown, Gysler, and Brachinger (1999) show that contextual framing of experiments has a paramount effect on the risk propensity of men and women. When lotteries are framed as gains, men are more risk-loving than women; however, when lotteries are framed in terms of losses, then men are more risk-averse than women. Dohmen, Falk, Huffman, Sunde, Schupp, and Wagner (2011) find - based on a representative survey of the German population (GSOEP) - that the gender gap in attitudes towards risk varies over the life cycle. The risk propensity of men decreases 
steadily with age. Women exhibit the largest decline in risk propensity between their late teens and age thirty. Risk propensity then stabilizes up until the mid-fifties and declines further thereafter. Thus, the gender gap varies with age. Johnson and Powell (1994), Atkinson, Baird, and Frye (2003) and Beckmann and Menkhoff (2008) document equal readiness of male and female fund managers to take risks. Recently, Berger, Kick, and Schaeck (2012) find that a higher proportion of women in the executive boards of banks is associated with a higher level of risk-taking by the institution.

Beside studies aiming at identifying the gender gap in financial risk-taking, there is also a large body of literature looking for an explanation of gender differences. Some of these studies link gender differences in economic behavior to biological factors. For instance, factors such as the hormone level and the structure of the brain have been found to be relevant for gender differences in behavioral patterns (see e.g. Blanco, Ibánez, Blanco-Jerez, Baca-Garcia, and Sáiz-Ruiz, 2001; Archer, 2006; Hermans, Putman, Baas, Koppeschaar, and van Honk, 2006). A number of studies document a link between the level of testosterone and gender differences in the likelihood of choosing a career in finance (Sapienza, Zingales, and Maestripieric, 2009), in the performance of financial professionals (Coates, Gurnell, and Rustichini, 2009) and in the propensity for financial risk-taking (Stenstrom, Saad, Nepomuceno, and Mendenhall, 2011; Apicella, Dreber, Campbell, Gray, Hoffman, and Little, 2008). Moreover, women's willingness to take financial risk has been shown to vary over the menstrual cycle (Bröder and Hohmann, 2003).

Increasingly, the literature also discusses social factors as an important determinant of gender differences in risk-taking behavior. Collective values and norms shape individual behavior in various domains of life and are likely to affect financial behavior as well (Carroll, Rhee, and Rhee, 1994; Fernández and Fogli, 2006; Giuliano, 2007; Haliassos, Christelis, and Georgarakos, 2010). They can also be responsible for the distinct behavioral patterns of men and women in financial decision-making. Finucane, Slovic, Mertz, Flynn, and Satterfield (2000), who study propensity for risk-taking by men and women in groups with different social background, find that gender differences vary significantly across ethnic groups in the USA. Gneezy, Leonard, and List (2008) follow a simple but convincing approach to show that social factors matter. They compare women's willingness to compete in two distinct societies - one society with a dominating patriarchal social norm and the other with a pronounced matriarchal organization. They find that in the patriarchal society more men choose to compete, while in the matriarchal society more women are willing to compete than men. Booth and Nolen (2012) confirm the crucial impact of the social environment, too. They show that girls from all-girl schools are as likely as boys from either coed or all-boy schools to choose a risky gamble, while girls from coed schools are more risk-averse than boys. Similar evidence is provided by Lindquist and Säve-Söderbergh (2011) who find in a natural experiment that females are more risk-averse when assigned to a male-dominated group, than if they are in a mixed or female-only group. 


\section{Hypothesis about the role of gender and its theo- retical foundation}

A review of previous studies gives an impression that the extent of risk actually taken by men and women may be determined by the prevailing gender roles in a society. One may expect that in a society where financial risk-taking is attributed to a male role rather than to a female role, women may shy away from risk-taking more than men, regardless of individual risk preferences. In other words, the actual risk-taking behavior of men and women may not always correspond to their individual risk preferences. Specifically, we make the following hypothesis regarding the role of gender and risk preferences in actual risk-taking. If gender inequality in a society is high, men and women with equal risk preferences can still differ in their actual risk-taking. In this case, gender should have a strong explanatory power for financial behavior apart from risk preferences. If gender inequality is low, men and women should act in accordance with their individual risk preferences. Here, gender should have a limited explanatory power for the financial behavior as soon as risk preferences are taken into account.

Akerlof and Kranton (2000) provide theoretical foundations for this hypothesis. Their paper suggests a general model of economic behavior in which the utility derived from an economic action depends on personal identity. Identity is defined as a person's sense of self or self-image. This image comprises such categories as gender, ethnicity, age etc. Each category is associated with a set of attributes and behaviors. Which attributes and behaviors are attached to a category is determined by social norms. For instance, the category gender can be viewed as a set of characteristics and behaviors that in a given society are associated with an ideal man or woman. By following the prescriptions of social norms, a person affirms his/her self-image, which leads to gains in identity. By violating the prescriptions, a person incurs losses to the identity. Hence, a person can experience gains or losses to identity depending on the extent to which an action corresponds to a socially prescribed behavior. This relationship has an important effect on the utility derived from economic actions. Identity enters as an argument into the individual utility function. A decrease in identity reduces utility. And, vice versa, a gain in identity entails an increase in utility. Hence, a dissonance between one's action and social norms reduces the utility derived from the action.

Following Akerlof and Kranton (2000), we can realistically assume that a utilitymaximizing individual will tend to adapt his/her behavior to social norms even when this causes him/her to deviate from individual preferences. The key implication of this relationship for risk-taking in financial decisions is as follows. In a society with asymmetric gender roles, where investing in risky assets is considered to be a male domain, it can be optimal for a risk-loving woman to act more risk-averse than she actually is. Similarly, it can also be optimal for a risk-averse man to act more risk-loving than is appropriate given his risk preferences, in order to fit the social prescriptions. Thus, in addition to the influence of risk preferences, gender can have an incremental effect on the behavior. In the remainder of the paper, we conduct an empirical test of whether investors' gender influences risk-taking beyond the effect captured in the investors' risk attitude. 


\section{Methodology}

Our approach to hypothesis testing is inspired by Gneezy et al. (2008). We analyze the behavior of men and women in societies that differ with respect to prevailing gender roles. However, instead of experimental data, we rely on surveys of household finances. Specifically, we focus on four European countries - Austria, the Netherlands, Spain and Italy. As shown in the next section, these four countries differ in the degree of gender equality. Moreover, these are the only four countries where information about investors' gender, actual risk-taking and risk preferences is collected in representative national household surveys.

\subsection{Data}

The data are assembled from several sources. The Spanish and Dutch data are drawn directly from the countries' representative national survey data sets: the Spanish Survey of Household Finances (EFF) Wave 2005 and the DNB Household Survey Wave 2004. Data for Austria and Italy are drawn from the Luxembourg Wealth Study (LWS) database; the original data were collected in the Austrian Survey of Household Financial Wealth Wave 2004 and the Italian Survey of Household Income and Wealth (SHIW) Wave 2004. ${ }^{4}$ Hence, for each country we have a cross-sectional data set with the household as a unit of observation.

Each country's data set contains information on both the self-reported risk preferences of the respondents and their actual risk-taking reflected in the asset holdings. Due to the data standardization in the LWS, the Austrian and the Italian data sets provide income and wealth information for the entire household and not for individual household members. The Spanish survey collects information about real and financial assets at the household level, while data on income is available at the level of individual household members. The Dutch survey collects all information items at the individual level. We calculate total household income for Spain and the Netherlands by summing the incomes across household members. The same method is used to calculate households' asset holdings for the Netherlands.

Individual specific characteristics like age, education or risk attitudes are reported for the household member who is primary responsible for the financial decisions of the entire household. The definition of who is the decision-maker in a household varies across the national surveys. In the Austrian survey, the decision-maker is the self-declared household head or the household member who has the most accurate knowledge about the household finances. In the Italian survey, this is the household member who declares him/herself as being primarily responsible for the household budget. In the Dutch survey, this is the person who declares him/herself as having the greatest influence on the financial decisions of the household. In the Spanish survey, this is the person who is responsible for the accommodation and also normally chiefly deals with the financial issues.

\footnotetext{
${ }^{4}$ For details about the surveys, see Beer, Mooslechner, Schürz, and Wagner (2006) (Austrian survey), Van Els, Van den End, and Van Rooij (2005) (Dutch survey), Bover (2008) (Spanish survey) and Faiella, Gambacorta, Iezzi, and Neri (2006) (Italian survey).
} 


\subsection{Measurement of gender equality}

The four European countries under examination differ with respect to gender roles, which is reflected in the degree of gender equality. Gender equality is measured based on the World Economic Forum's Gender Gap Index. The Gender Gap Index is a composite index calculated for 134 countries. The index takes into account differences between men and women in a given country with respect to access to resources and opportunities in four domains of social life: participation in the labor markets and earnings, educational attainment, political empowerment, health and survival. Based on the index, each country obtains a rating starting with 1 (lowest gender inequality). As reported by the Gender Gap Report, in 2006, Scandinavian countries ranked the best. The four European countries that we look at ranked as follows: Spain 11th, the Netherlands 12th, Austria 27th and Italy 77th. Hence, with respect to gender equality, Italy falls significantly behind the other three countries.

The Gender Gap Index has previously proved to be a useful source of information in gender-related research. For instance, Guiso, Monte, Sapienza, and Zingales (2008) employ the index to investigate whether the degree of sexism in 40 countries relates to cross-country variation in the gender gap in math scores. They find that the gender gap disappears in more gender-equal societies. A related study by Cardenás, Dreber, von Essen, and Ranehill (2011) explores gender differences in preferences for competition and risk-taking among children in Colombia and Sweden - two countries significantly differing in gender equality. Although boys are found to be more risk-prone than girls in both countries, the gender gap is smaller in the more gender-egalitarian Sweden.

We use the index to explain gender differences in financial risk-taking. Unfortunately, we cannot include all the countries from the Gender Gap Report in our analysis because some lack appropriate data about financial behavior and risk preferences. This means that the pool of countries is too small to conduct a formal statistical test of the causality between the degree of gender equality and financial risk-taking. However, we will analyze the behavior of men and women for each country individually and test whether the results obtained for the egalitarian country with the highest gender inequality in our sample differ from the other three countries.

\subsection{Actual risk taken}

The extent of risk taken is measured along two dimensions of decision-making with respect to financial portfolios. The first dimension regards the decision on whether or not to include risky financial assets in the portfolio. We call this the participation decision. An investor holding some risky assets is considered to take more risks than someone who does not own them. Information on participation is operationalized by a dummy variable equal to 1 if a household holds some risky financial assets and 0 otherwise.

The second dimension of financial risk-taking under examination regards the decision about the share of the financial portfolio allocated to risky assets. We refer to it as the allocation decision. The higher the share of risky assets in a household's portfolio, the more risk it takes. This measure of riskiness is defined following the approach first proposed by Friend and Blume (1975) and then adapted in a number of empirical studies (e.g. Guiso, Haliassos, and Jappelli, 2002). According to this approach, a risk-averse investor allocates his/her wealth between risk free and risky assets in proportions that 
Figure 1: Participation rates and portfolio shares of stocks

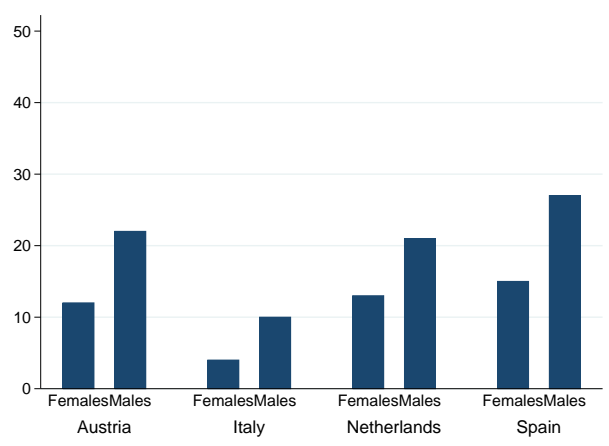

a) Participation rate

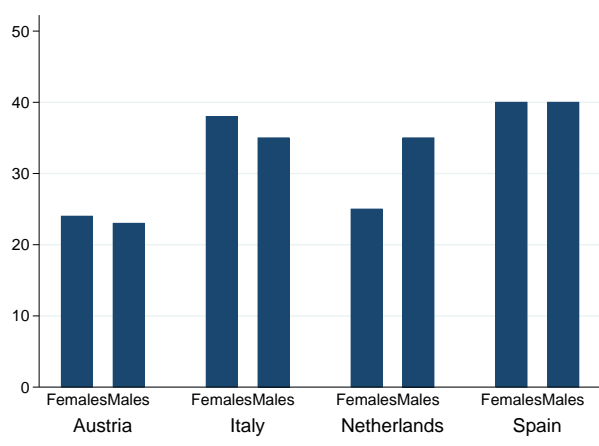

b) Average portfolio share

maximize the investor's utility. The share of risky assets is proportional to the ArrowPratt measure of risk aversion and reflects the investor's risk preferences. The higher the portfolio share allocated to risky assets, the more risky the portfolio is. We acknowledge, however, that this is quite a simplified approach to measure risk, as we do not know the variation of returns on the risky assets.

Risky financial assets in our study comprise only directly held stocks. Under this definition, stocks held through mutual funds or other risky securities are not considered. This narrow definition is due to the data limitations. Specifically, while having information about ownership of investment funds and wealth allocated to them, we do not know the composition of the investment funds; nor do we have information about holdings of other risky securities like derivatives. Ignoring other financial securities should not be critical as the participation and the share of these instruments in household portfolios is generally small (Guiso and Sodini, 2012). In contrast, indirect stock ownership through mutual funds is widely spread among households and its portfolio share is significant (Guiso et al., 2002; Guiso and Sodini, 2012). Thus, ignoring investments in mutual funds may lead to a significant underestimation of portfolios' riskiness. Moreover, recent analyzes reveal strong gender differences in the choice of stock holding mode. Conditional on ownership of stocks in any form, single males are found to be more willing to invest in stocks directly, while females with similar characteristics seem to prefer holding stocks through mutual funds (Christelis, Georgarakos, and Haliassos, 2011). Hence, by not considering mutual funds, we may underestimate the risks taken by females more than those taken by males. In order to test the sensitivity of our analysis with respect to the definition of risky assets, we will run a robustness check including both directly held stocks and mutual funds as risky assets.

Based on the data on the holdings of financial assets, for each country we calculate the participation rate for risky financial assets, i.e. the proportion of individuals in a country who hold risky assets in their portfolios. The calculated participation rates differ between gender groups and across countries (see Figure 1a). The common pattern shared by all countries is that the participation rate is higher among men than women. However, the magnitude of the gender gap varies between countries. The largest gap - 12 percentage points - is observed in Spain, followed by Austria with a 10 percent gap, the Netherlands 
with an 8 percent gap and Italy with a 3 percent gap. In all four countries, the higher participation rates observed for men are statistically significant. ${ }^{5}$

Interestingly, there is no such clear gender difference in the share of risky assets. In Austria and Italy, women even seem to allocate, on average, a bigger portfolio share to stocks than men, although the difference is not statistically significant (see Figure 1b). The shares of men and women are similar in Spain. Only in the Netherlands do women have a smaller share of stocks than men, by 10 percent, although this difference is again not statistically significant.

\subsection{Risk preferences}

Individual risk preferences are a crucial piece of information in our framework. This information is obtained in the household surveys by asking the respondents to provide an assessment of their willingness to take financial risks. The exact formulation of the questions and the scales on which the extent of willingness is measured vary across the four national surveys (see Table 10 in the Appendix). The Dutch survey applies a 7-point scale, whereas the Austrian, Italian and Spanish surveys use a less detailed 4-point scale. ${ }^{6}$ Based on the original categorization of risk preferences, we generate a set of dummy variables Risk Tolerance $j$ with $j=[1,4]$ for Austria, Italy and Spain and $j=[1,7]$ for the Netherlands. ${ }^{7}$ Higher values of $j$ correspond to greater willingness to take risk and, therefore, indicate a higher risk tolerance.

Figure 2 presents the country-specific distribution of men and women by self-reported tolerance towards financial risk. In all countries, women clearly outnumber men in the group with the lowest risk tolerance. According to a two-sided T-test, differences are statistically significant at the $1 \%$ level. At higher levels of risk tolerance (Risk Tolerance

\footnotetext{
${ }^{5}$ We test the significance using a two-tailed T-test.

${ }^{6}$ While processing the data, we discovered that the Italian data set is characterized by a high rate of non-response to the question regarding the willingness to take financial risk: about 65 percent of respondents skipped the question. For our analysis, non-responses mean that all observations with missing data are excluded from the data set, which leads to a significant reduction of the sample. In order to see whether the decision to report risk attitude is influenced by some individual characteristics, we fit the data to a probit regression model. The dependent variable in this model is an indicator variable equal to 1 if risk attitude is reported and 0 if risk attitude is missing. Explanatory variables include sex, age, income, wealth, employment status, education, family structure and an indicator variable equal to 1 if risky assets are owned and 0 otherwise. Our results show that the probability of non-response is negatively related to income, wealth, and holdings of risky financial assets, and is smaller for those who are employed than for those who are unemployed. Gender does not affect the reporting of risk attitude. Thus, the sub-set of individuals who provide information on their risk attitudes is wealthier and, therefore, more homogeneous with respect to financial resources than the overall population. When testing our research hypothesis, this greater homogeneity could bias our results toward finding no gender effects.

${ }^{7}$ For Spain, we reverse the scale in order to allow higher values to express greater subjective willingness to take risks. Thus, the dummy variable Risk Tolerance 1 equals one if a respondent chose the 4 th alternative, Risk Tolerance 2 equals one if the 3rd alternative was chosen, Risk Tolerance 3 equals one if the 2 nd alternative was chosen and RiskTolerance 4 equals one if the 1 st alternative was chosen. For the Netherlands, we also tried to pool the risk groups together in order to reduce the number of categories from 7 to 4 . Specifically, we pooled the 2 nd and the 3 rd group together and the 5 th, the 6 th and the 7 th together. However, using the 4 dummies instead of 7 did not change our results in the subsequent regression analysis. We therefore decided to leave the original division into 7 groups.
} 
Figure 2: Distribution of individuals by the self-reported willingness to take financial risk (subjective risk tolerance)
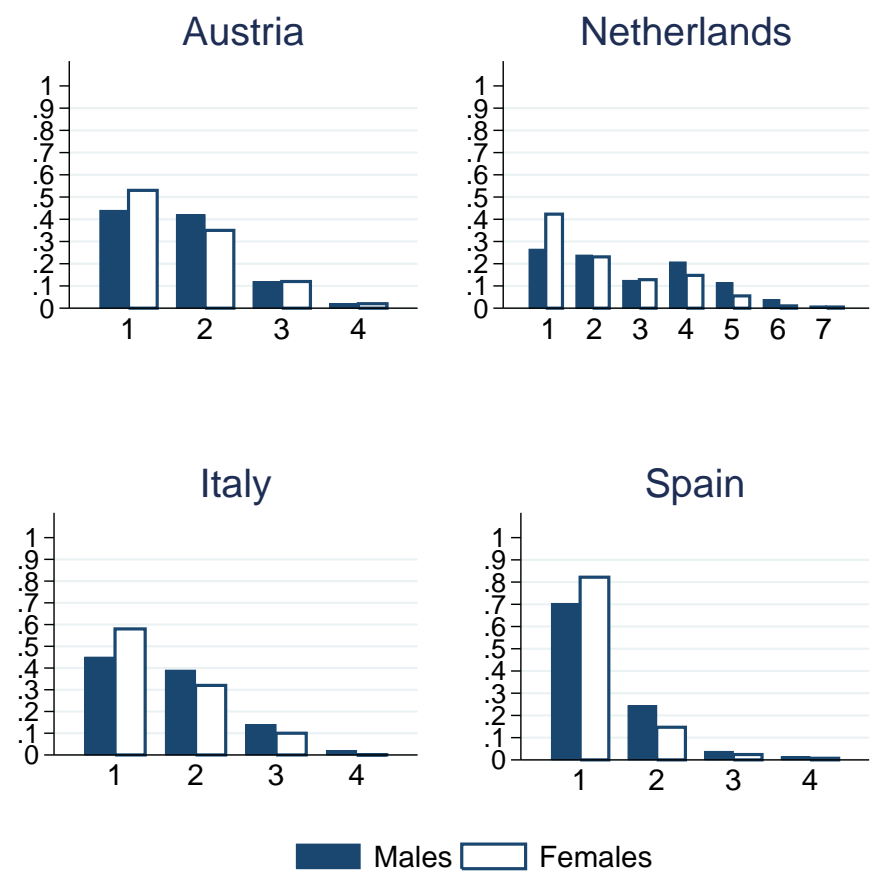

Note: Each histogram shows country-specific distributions of men and women according to the self-reported risk tolerance. The degree of risk tolerance is measured on an ordinal scale with higher numbers corresponding to higher risk tolerance.

$\geq 2$ ), the proportion of men exceeds the proportion of women, although the differences are not statistically significant.

\section{$5 \quad$ Econometric model}

Given the two aspects of risk-taking, participation and allocation, we formulate two testable hypotheses regarding the extent of financial risk taken by men and women in our sample. Since we expect country-specific social norms to play a role in shaping the extent of risk-taking, our hypotheses read:

HYPOTHESIS 1: "Participation decision"

Men are more likely to invest in risky assets than women with equal risk attitude if the degree of gender inequality in the country is high, ceteris paribus.

HYPOTHESIS 2: "Allocation decision"

Men allocate a larger share of their financial portfolios to risky assets than women with equal risk attitude if the degree of gender inequality in the country is high, ceteris paribus.

To test the first hypothesis, we estimate the effects of gender on the probability of holding risky assets using a probit regression. We refer to this regression model as Model $I$. The dependent variable is a binary variable equal to 1 if an investor owns some risky 
assets and 0 otherwise. The effect of gender is captured by the binary variable Male, equal to 1 if an investor is male and 0 if female. A positive and statistically significant coefficient on this variable would indicate that, ceteris paribus, men are more likely to invest in risky financial assets than women.

To test our second hypothesis, we rely on a Heckman regression. According to Haliassos and Bertaut (1995), an investor will not hold any risky assets if the utility gained from ownership of the optimal amount is smaller than the incurred participation costs. Hence, holdings of risky assets are observed only for some investors, while they are censored at zero for the rest. The non-random selection of individuals according to those who own risky assets and those who do not potentially leads to the sample selection bias. This bias is likely to emerge when the decision to hold risky assets and the decision about the amount of these assets are correlated either through observable characteristics of individuals or via common factors. For example, one such factor is individual financial knowledge, which certainly affects both decisions but is rarely observed by researchers. A suitable econometric approach in this case is the Heckman sample selection model. ${ }^{8}$ The model represents the portfolio decision as a two-step procedure. The first step is whether to own risky assets. Accordingly, we estimate the probit model with a binary dependent variable equal to 1 if an investor owns some risky assets and 0 otherwise. From this regression, we obtain the correction term Mills Ratio which is then included in the second-stage regression equation. The second-stage equation has the share of financial wealth allocated to risky assets as the dependent variable and, hence, depicts investors' allocation decision. In the following, we refer to this two-stage regression model as Model II. As in the first hypothesis, the effect of gender in Model II is captured by the binary variable Male that is included in the regression at both stages of the Heckman estimation. The estimated coefficient of the explanatory variable Male in the second-stage equation would show whether men tend to hold larger shares of risky assets than women, ceteris paribus.

In both models, we account for investors' individual risk attitudes. We expect that individual attitudes towards financial risk will affect investment decisions independently of the other socioeconomic and demographic characteristics. Moreover, if individuals act in accordance with their risk preferences, then risk preferences should predict the actual risk-taking behavior better than gender. In this case, investors' gender should lose its explanatory power as soon as individual risk attitudes are accounted for. To test this prediction, we estimate two different specifications of each model (Model I and Model II). The first specification is the so-called naive model, which captures the gross effect of gender. It includes all observable socioeconomic variables, including gender, but excluding the measure of risk attitude. The second specification, the advanced model, additionally includes a set of dummy variables capturing the subjective risk tolerance. Table 1 summarizes the model specifications.

The rest of the explanatory variables in both models are chosen in line with existing

\footnotetext{
${ }^{8} \mathrm{~A}$ linear regression can produce biased results as it takes into account neither censoring nor the sample selection. The Tobit estimation technique would deal with the left-hand censoring problem but not with sample selection. Instead, the two-stage approach to the modeling of portfolio decisions by private investors deals appropriately with the sample-selection problem as is being increasingly applied in empirical studies of household finances. See, for example, Guiso, Haliassos, Jappelli, and Claessens (2003), Guiso et al. (2002).
} 
Table 1: Model specifications

\begin{tabular}{l|l|l}
\hline & Naive model & Advanced model \\
\hline $\begin{array}{l}\text { Model I: Probit } \\
\text { (Participation decision) }\end{array}$ & $\begin{array}{l}\text { Gender } \\
+ \text { control variables }\end{array}$ & $\begin{array}{l}\text { Gender } \\
+ \text { risk preferences } \\
+ \text { control variables }\end{array}$ \\
\hline $\begin{array}{l}\text { Model II: Heckman } \\
\text { (Allocation decision) }\end{array}$ & $\begin{array}{l}\text { Gender } \\
+ \text { control variables }\end{array}$ & $\begin{array}{l}\text { Gender } \\
+ \text { risk preferences } \\
+ \text { control variables }\end{array}$ \\
\hline
\end{tabular}

literature on the role of household characteristics in the portfolio decisions. Firstly, we describe variables included in Model II. An important determinant of portfolio decisionmaking is income. In the presence of transactions costs associated with financial market participation, income should have a positive effect on ownership of risky financial assets. We control for the effect of income by including the logarithm of the household's net income $\ln$ (Income). Total financial wealth should also affect portfolio decisions. As shown by Guiso et al. (2003), the effect of wealth on the ownership of risky assets is nonlinear. At very low levels of wealth, high transaction costs may prevent a household from participating in the financial markets. The probability of holding risky assets should be close to zero. At high levels of wealth there will be a positive probability of holding risky assets which may be constant over wealth. To allow a flexible pattern of wealth effect, we include four dummy variables I wealth quartile, II wealth quartile, III wealth quartile and $I V$ wealth quartile indicating to which quartile of the wealth sample distribution the household belongs. Guiso et al. (2003) document a hump-shaped relation between age and holdings of risky assets by households in European countries. In particular, the participation rate among the young and elderly is low compared to the middle-aged households. To capture this non-linearity, we include 6 dummies indicating age groups: Age < 20, Age $30-39$, Age 40 - 49, Age 50 - 59, Age $60-69$ and Age $\geq 70$, each equal to 1 if an individual falls into the respective age group. Following a number of theoretical and empirical studies pointing at the important role of house ownership in the investment decisions ${ }^{9}$, we include an indicator of ownership of residential property (dummy variable RealProperty). Education is another important factor in the ownership decision, since it may be associated with informational costs of participation in the financial markets, and also with financial literacy. A dummy variable Education equals 1 if the respondent earned a college (or higher) degree and 0 otherwise. We also control for the marital status of the household's head and the presence of children, as these factors are likely to affect portfolio decisions through a bequest motive; moreover they may be also correlated with unobservable socioeconomic factors affecting portfolio choice. A dummy variable Single equals 1 if the individual is single and 0 otherwise. The continuous variable Children captures the number of children under the age of 18. As advocated by Guiso et al. (2008), individuals facing high labor income risk are more risk-averse and could thus avoid exposure to portfolio risk by holding less or no risky assets. Our data do not allow to measure income risk properly. However, to capture an additional background risk resulting from risky entrepreneurial income, we include a binary variable Self-Employed

\footnotetext{
${ }^{9}$ See e.g. Chetty and Szeidl (2007).
} 
Table 2: Descriptive statistics by gender

\begin{tabular}{|c|c|c|c|c|c|c|c|c|}
\hline & \multicolumn{2}{|c|}{ Austria } & \multicolumn{2}{|c|}{ Netherlands } & \multicolumn{2}{|c|}{ Italy } & \multicolumn{2}{|c|}{ Spain } \\
\hline & Women & Men & Women & Men & Women & Men & Women & Men \\
\hline Income, in euro & $\begin{array}{c}25,256 \\
(13,024)\end{array}$ & $\begin{array}{c}33,966 \\
(13,680)\end{array}$ & $\begin{array}{c}25,605 \\
(21,712)\end{array}$ & $\begin{array}{c}31,165 \\
(26,717)\end{array}$ & $\begin{array}{c}19,838 \\
(15,873)\end{array}$ & $\begin{array}{c}27,346 \\
(28,211)\end{array}$ & $\begin{array}{c}23,312 \\
(32,066)\end{array}$ & $\begin{array}{c}35,797 \\
(50,268)\end{array}$ \\
\hline Financial Wealth, in euro & $\begin{array}{c}29,576 \\
(53,172)\end{array}$ & $\begin{array}{c}56,866 \\
(120,099)\end{array}$ & $\begin{array}{c}9,889 \\
(24,813)\end{array}$ & $\begin{array}{c}23,602 \\
(70,186)\end{array}$ & $\begin{array}{c}15,728 \\
(55,712)\end{array}$ & $\begin{array}{c}25,404 \\
(72,627)\end{array}$ & $\begin{array}{c}31,755 \\
(88,371)\end{array}$ & $\begin{array}{c}64,411 \\
(135,367)\end{array}$ \\
\hline Real Property & $\begin{array}{c}0.53 \\
(0.50)\end{array}$ & $\begin{array}{c}0.65 \\
(0.48)\end{array}$ & $\begin{array}{c}0.70 \\
(0.46)\end{array}$ & $\begin{array}{c}0.71 \\
(0.45)\end{array}$ & $\begin{array}{c}0.67 \\
(0.47)\end{array}$ & $\begin{array}{c}0.72 \\
(0.45)\end{array}$ & $\begin{array}{c}0.41 \\
(0.49)\end{array}$ & $\begin{array}{c}0.65 \\
(0.48)\end{array}$ \\
\hline Self-Employed & $\begin{array}{c}0.05 \\
(0.23)\end{array}$ & $\begin{array}{c}0.08 \\
(0.27)\end{array}$ & $\begin{array}{c}0.03 \\
(0.17)\end{array}$ & $\begin{array}{c}0.05 \\
(0.21)\end{array}$ & $\begin{array}{c}0.05 \\
(0.22)\end{array}$ & $\begin{array}{c}0.14 \\
(0.35)\end{array}$ & $\begin{array}{c}0.06 \\
(0.23)\end{array}$ & $\begin{array}{c}0.18 \\
(0.38)\end{array}$ \\
\hline Education & $\begin{array}{c}0.43 \\
(0.50)\end{array}$ & $\begin{array}{c}0.39 \\
(0.49)\end{array}$ & $\begin{array}{c}0.23 \\
(0.42)\end{array}$ & $\begin{array}{c}0.24 \\
(0.42)\end{array}$ & $\begin{array}{c}0.32 \\
(0.47)\end{array}$ & $\begin{array}{c}0.41 \\
(0.49)\end{array}$ & $\begin{array}{c}0.20 \\
(0.40)\end{array}$ & $\begin{array}{c}0.29 \\
(0.45)\end{array}$ \\
\hline Age $\leq 30$ & $\begin{array}{c}0.08 \\
(0.27)\end{array}$ & $\begin{array}{c}0.05 \\
(0.22)\end{array}$ & $\begin{array}{c}0.08 \\
(0.26)\end{array}$ & $\begin{array}{c}0.04 \\
(0.20)\end{array}$ & $\begin{array}{c}0.04 \\
(0.19)\end{array}$ & $\begin{array}{c}0.03 \\
(0.17)\end{array}$ & $\begin{array}{c}0.05 \\
(0.22)\end{array}$ & $\begin{array}{c}0.03 \\
(0.18)\end{array}$ \\
\hline Age 30-39 & $\begin{array}{c}0.20 \\
(0.40)\end{array}$ & $\begin{array}{c}0.14 \\
(0.35)\end{array}$ & $\begin{array}{c}0.24 \\
(0.43)\end{array}$ & $\begin{array}{c}0.19 \\
(0.39)\end{array}$ & $\begin{array}{c}0.13 \\
(0.34)\end{array}$ & $\begin{array}{c}0.13 \\
(0.33)\end{array}$ & $\begin{array}{c}0.14 \\
(0.35)\end{array}$ & $\begin{array}{c}0.11 \\
(0.31)\end{array}$ \\
\hline Age $40-49$ & $\begin{array}{c}0.21 \\
(0.40)\end{array}$ & $\begin{array}{c}0.25 \\
(0.43)\end{array}$ & $\begin{array}{c}0.25 \\
(0.43)\end{array}$ & $\begin{array}{c}0.23 \\
(0.42)\end{array}$ & $\begin{array}{c}0.18 \\
(0.39)\end{array}$ & $\begin{array}{c}0.19 \\
(0.39)\end{array}$ & $\begin{array}{c}0.20 \\
(0.40)\end{array}$ & $\begin{array}{c}0.17 \\
(0.38)\end{array}$ \\
\hline Age 50-59 & $\begin{array}{c}0.18 \\
(0.38)\end{array}$ & $\begin{array}{c}0.19 \\
(0.40)\end{array}$ & $\begin{array}{c}0.22 \\
(0.41)\end{array}$ & $\begin{array}{c}0.23 \\
(0.42)\end{array}$ & $\begin{array}{c}0.18 \\
(0.38)\end{array}$ & $\begin{array}{c}0.24 \\
(0.42)\end{array}$ & $\begin{array}{c}0.17 \\
(0.38)\end{array}$ & $\begin{array}{c}0.20 \\
(0.40)\end{array}$ \\
\hline Age $60-69$ & $\begin{array}{c}0.20 \\
(0.40)\end{array}$ & $\begin{array}{c}0.24 \\
(0.43)\end{array}$ & $\begin{array}{c}0.14 \\
(0.34)\end{array}$ & $\begin{array}{c}0.17 \\
(0.37)\end{array}$ & $\begin{array}{c}0.16 \\
(0.37)\end{array}$ & $\begin{array}{c}0.21 \\
(0.41)\end{array}$ & $\begin{array}{c}0.18 \\
(0.38)\end{array}$ & $\begin{array}{c}0.24 \\
(0.43)\end{array}$ \\
\hline Age $\geq 70$ & $\begin{array}{c}0.13 \\
(0.34)\end{array}$ & $\begin{array}{c}0.12 \\
(0.32)\end{array}$ & $\begin{array}{c}0.08 \\
(0.27)\end{array}$ & $\begin{array}{c}0.15 \\
(0.35)\end{array}$ & $\begin{array}{c}0.31 \\
(0.46)\end{array}$ & $\begin{array}{c}0.21 \\
(0.41)\end{array}$ & $\begin{array}{c}0.26 \\
(0.44)\end{array}$ & $\begin{array}{c}0.25 \\
(0.44)\end{array}$ \\
\hline Single & $\begin{array}{c}0.69 \\
(0.46)\end{array}$ & $\begin{array}{c}0.21 \\
(0.41)\end{array}$ & $\begin{array}{c}0.36 \\
(0.48)\end{array}$ & $\begin{array}{c}0.30 \\
(0.46)\end{array}$ & $\begin{array}{c}0.62 \\
(0.49)\end{array}$ & $\begin{array}{c}0.19 \\
(0.40)\end{array}$ & $\begin{array}{c}0.49 \\
(0.50)\end{array}$ & $\begin{array}{c}0.19 \\
(0.39)\end{array}$ \\
\hline Children & $\begin{array}{c}0.40 \\
(0.84)\end{array}$ & $\begin{array}{c}0.50 \\
(0.92)\end{array}$ & $\begin{array}{c}0.83 \\
(1.11)\end{array}$ & $\begin{array}{c}0.72 \\
(1.11)\end{array}$ & $\begin{array}{c}0.32 \\
(0.70)\end{array}$ & $\begin{array}{c}0.41 \\
(0.77)\end{array}$ & $\begin{array}{c}0.77 \\
(0.94)\end{array}$ & $\begin{array}{c}0.79 \\
(0.95)\end{array}$ \\
\hline
\end{tabular}

Note: The table reports country-specific sample means and standard deviations (in parentheses); the variable Financial Wealth is winsorized to $99 \%$.

indicating the self-employment status of the household head.

As regards Model II, the choice of explanatory variables for the first-stage equation corresponds to that used in the analysis of the ownership decision (Model I). The secondstage equation includes largely the same variables as the first-stage equation with two adjustments that enable the identification restriction. Firstly, in line with Guiso et al. (2008), we expect that the share of risky assets is a concave increasing function of wealth. We therefore include a logarithm of household financial wealth $\ln$ (Financial Wealth) instead of dummies for wealth quartiles in the equation. Secondly, the dummy variable Property is excluded from the equation. Property ownership could influence the decision to participate in the markets for risky financial assets as it can bind resources, leaving nothing to invest in financial assets or, alternatively, if resources are sufficient, an investor may be willing to hold both real and financial assets for the sake of diversification. However, property ownership should not affect the optimal share of risky assets in the portfolio. The mere fact of house ownership is irrelevant for the allocation decision. What could matter is the value of real assets and its correlation with returns on risky financial assets.

The descriptive statistics of variables are summarized in Table 2. In all countries, men earn more, have higher financial wealth and more often own residential property. The percentage of self-employed individuals is higher throughout the sample and, with the exception of Austria, men more frequently have a high level of education. 


\section{Results}

We first estimate the effects of gender on the probability of investing in risky assets (Hypothesis 1: participation decision) using probit regression (Model I). ${ }^{10}$ Then, in a second step, we estimate the impact of gender on the share of risky assets in the portfolio (Hypothesis 2: allocation decision) using the Heckman regression technique (Model II).

\subsection{Effects of gender on the probability of owning risky assets}

In this section, we report our findings regarding the link between the likelihood of investing in risky assets and gender. Table 3 shows the estimation results. It reports marginal effects for the participation decision estimated for country-specific means of continuous variables and for base categories of dummy and categorical variables. The results for each country's naive model are given in column (1). Column (2) shows the estimates for the advanced model with risk tolerance levels included. The inclusion increases $R^{2}$ compared to the naive model. Hence, accounting for risk attitudes improves the explanatory power of the regression.

In line with our expectations, the probability of risky assets in the portfolio increases significantly with wealth. Education is also found to increase the likelihood of ownership in all countries. However, in the Netherlands the effect is not statistically significant. Effects of real property, age and family status differ across countries. ${ }^{11}$

It is obvious that the results obtained for the naive model seem to confirm the common belief that the willingness to actually take investment risk is sex-linked. The coefficients on the dummy variable Male are positive and statistically significant. Ceteris paribus, men are more likely to invest in risky assets than women by about 4 percentage points in Austria, by 8 percent in the Netherlands, by 9 percent in Italy and by 2 percent in Spain. If these results were the end of the story, we would conclude that the gender stereotype can be confirmed and that gender serves as a strong predictor of risk-taking. We could then say that it is appropriate for the financial advice to be geared to the risk propensity of an "average" woman and an "average" man.

Yet, the picture changes when we look at the estimation results obtained for the second model specification. Controlling for risk attitudes renders coefficients on the dummy variable Male statistically insignificant in Austria, the Netherlands and Spain. At the same time, coefficients on risk tolerance dummies are all highly significant. They show, that the probability of investing increases with risk tolerance. Thus, Hypothesis 1 cannot be confirmed. A different finding emerges for Italy. Here, the dummy variable Male remains significant, even after we control for risk tolerance. Holding risk tolerance constant, men are almost 8 percent more likely to invest in risky assets than women. Thus, Hypothesis 1 can be confirmed for Italy. Here, men are more likely to acquire risky assets than women with the same degree of risk tolerance.

\footnotetext{
${ }^{10}$ We also estimate the equation using a logit regression model. The log-likelihood for the probit model is, however, higher than for the logit model in all five countries, favoring the probit model.

${ }^{11}$ The differences in the estimated effects may be caused by cross-country differences in factors that have common effects on the behavior of individuals regardless of their gender. For example, Guiso et al. (2003) consider differences in national capital gains taxes, fixed costs of participation in the financial markets and financial literacy as important determinants of investment decisions.
} 
Table 3: Effect of gender on the probability of owning risky assets (participation decision)

This table shows the results from estimating the likelihood of holding risky assets using a probit regression model (Model $I$ ). The dependent variable is a binary variable equal to 1 if some risky financial assets are held and 0 otherwise. Columns denoted as (1) report estimation results for the basic specification without risk tolerance dummies (naive model). Columns denoted as (2) extend the specification by including variables capturing risk tolerance levels. Marginal effects of the explanatory variables are reported with the robust standard errors in parentheses. Marginal effects are estimated at country-specific mean values of explanatory variables. *, ** and *** correspond to the $10 \%, 5 \%$ and $1 \%$ significance levels, respectively. AIC $=$ Akaike Information Criterion, BIC $=$ Bayesian Information Criterion.

\begin{tabular}{|c|c|c|c|c|c|c|c|c|}
\hline & \multicolumn{2}{|c|}{ Austria } & \multicolumn{2}{|c|}{ Netherlands } & \multicolumn{2}{|c|}{ Italy } & \multicolumn{2}{|c|}{ Spain } \\
\hline & (1) & $(2)$ & (1) & $(2)$ & (1) & $(2)$ & (1) & (2) \\
\hline Male & $\begin{array}{c}0.039 * * * \\
(0.014)\end{array}$ & $\begin{array}{c}0.021 \\
(0.015)\end{array}$ & $\begin{array}{c}0.085^{* * *} \\
(0.027)\end{array}$ & $\begin{array}{c}0.044 \\
(0.031)\end{array}$ & $\begin{array}{c}0.087^{* * *} \\
(0.016)\end{array}$ & $\begin{array}{c}0.075^{* * *} \\
(0.016)\end{array}$ & $\begin{array}{l}0.020^{*} \\
(0.010)\end{array}$ & $\begin{array}{c}0.011 \\
(0.010)\end{array}$ \\
\hline $\ln$ (Income) & $\begin{array}{c}0.095^{* * *} * \\
(0.018)\end{array}$ & $\begin{array}{c}0.080^{* * *} \\
(0.018)\end{array}$ & $\begin{array}{l}-0.002 \\
(0.003)\end{array}$ & $\begin{array}{l}-0.007 \\
(0.005)\end{array}$ & $\begin{array}{c}0.117^{* * *} \\
(0.016)\end{array}$ & $\begin{array}{c}0.102^{* * *} \\
(0.015)\end{array}$ & $\begin{array}{c}0.007^{* * * *} \\
(0.002)\end{array}$ & $\begin{array}{c}0.005^{* *} \\
(0.002)\end{array}$ \\
\hline II Wealth quartile & $\begin{array}{c}0.129 * * * \\
(0.037)\end{array}$ & $\begin{array}{c}0.156^{* * *} \\
(0.04)\end{array}$ & $\begin{array}{l}-0.006 \\
(0.034)\end{array}$ & $\begin{array}{l}-0.043 \\
(0.046)\end{array}$ & $\begin{array}{c}0.191 \\
(0.145)\end{array}$ & $\begin{array}{c}0.268^{* *} \\
(0.135)\end{array}$ & $\begin{array}{c}0.155^{* * *} \\
(0.031)\end{array}$ & $\begin{array}{c}0.159^{* * *} \\
(0.032)\end{array}$ \\
\hline III Wealth quartile & $\begin{array}{c}0.258^{* * *} \\
(0.04)\end{array}$ & $\begin{array}{c}0.286^{* * *} * \\
(0.043)\end{array}$ & $\begin{array}{c}0.107 * * * \\
(0.035)\end{array}$ & $\begin{array}{c}0.138^{* * *} \\
(0.043)\end{array}$ & $\begin{array}{c}0.262^{* *} \\
(0.13)\end{array}$ & $\begin{array}{c}0.298^{* * *} \\
(0.115)\end{array}$ & $\begin{array}{c}0.424^{* * *} * \\
(0.032)\end{array}$ & $\begin{array}{c}0.415^{* * *} \\
(0.033)\end{array}$ \\
\hline IV Wealth quartile & $\begin{array}{c}0.524^{* * *} \\
(0.042)\end{array}$ & $\begin{array}{c}0.526^{* * *} \\
(0.044)\end{array}$ & $\begin{array}{c}0.234^{* * *} \\
(0.041)\end{array}$ & $\begin{array}{c}0.309 * * * \\
(0.045)\end{array}$ & $\begin{array}{c}0.286^{* * *} \\
(0.084)\end{array}$ & $\begin{array}{c}0.292^{* * *} \\
(0.071)\end{array}$ & $\begin{array}{c}0.665^{* * *} \\
(0.025)\end{array}$ & $\begin{array}{c}0.622^{* * *} \\
(0.028)\end{array}$ \\
\hline Real Property & $\begin{array}{c}0.042^{* * *} \\
(0.013)\end{array}$ & $\begin{array}{c}0.040^{* * *} \\
(0.012)\end{array}$ & $\begin{array}{c}0.061^{* * *} \\
(0.021)\end{array}$ & $\begin{array}{c}0.057^{* *} \\
(0.027)\end{array}$ & $\begin{array}{c}0.023 \\
(0.019)\end{array}$ & $\begin{array}{c}0.013 \\
(0.019)\end{array}$ & $\begin{array}{l}-0.016 \\
(0.013)\end{array}$ & $\begin{array}{c}-0.008 \\
(0.013)\end{array}$ \\
\hline Self-Employed & $\begin{array}{l}-0.001 \\
(0.024)\end{array}$ & $\begin{array}{l}-0.017 \\
(0.021)\end{array}$ & $\begin{array}{c}0.034 \\
(0.055)\end{array}$ & $\begin{array}{l}-0.032 \\
(0.069)\end{array}$ & $\begin{array}{l}-0.013 \\
(0.022)\end{array}$ & $\begin{array}{l}-0.021 \\
(0.021)\end{array}$ & $\begin{array}{c}0.038^{* * *} \\
(0.015)\end{array}$ & $\begin{array}{c}0.017 \\
(0.014)\end{array}$ \\
\hline Education & $\begin{array}{c}0.049^{* * *} \\
(0.014)\end{array}$ & $\begin{array}{c}0.047^{* * *} \\
(0.014)\end{array}$ & $\begin{array}{c}0.034 \\
(0.023)\end{array}$ & $\begin{array}{c}0.020 \\
(0.030)\end{array}$ & $\begin{array}{c}0.109^{* * *} * \\
(0.026)\end{array}$ & $\begin{array}{c}0.082^{* * *} * \\
(0.025)\end{array}$ & $\begin{array}{c}0.106^{* * *} \\
(0.013)\end{array}$ & $\begin{array}{c}0.080^{* * *} \\
(0.012)\end{array}$ \\
\hline Age $30-39$ & $\begin{array}{c}-0.055^{* *} \\
(0.023)\end{array}$ & $\begin{array}{c}-0.04 \\
(0.024)\end{array}$ & $\begin{array}{c}0.070 \\
(0.070)\end{array}$ & $\begin{array}{c}0.124 \\
(0.093)\end{array}$ & $\begin{array}{l}0.202^{*} \\
(0.104)\end{array}$ & $\begin{array}{c}0.133 \\
(0.100)\end{array}$ & $\begin{array}{l}-0.023 \\
(0.034)\end{array}$ & $\begin{array}{l}-0.026 \\
(0.033)\end{array}$ \\
\hline Age $40-49$ & $\begin{array}{c}-0.095 * * * \\
(0.020)\end{array}$ & $\begin{array}{c}-0.075^{* * *} \\
(0.021)\end{array}$ & $\begin{array}{c}0.047 \\
(0.066)\end{array}$ & $\begin{array}{c}0.112 \\
(0.091)\end{array}$ & $\begin{array}{l}0.191^{*} \\
(0.098)\end{array}$ & $\begin{array}{c}0.136 \\
(0.096)\end{array}$ & $\begin{array}{l}-0.000 \\
(0.036)\end{array}$ & $\begin{array}{l}-0.005 \\
(0.036)\end{array}$ \\
\hline Age 50-59 & $\begin{array}{c}-0.107 * * * \\
(0.017)\end{array}$ & $\begin{array}{c}-0.081^{* * *} \\
(0.019)\end{array}$ & $\begin{array}{c}0.042 \\
(0.063)\end{array}$ & $\begin{array}{c}0.126 \\
(0.088)\end{array}$ & $\begin{array}{l}0.156^{*} \\
(0.092)\end{array}$ & $\begin{array}{l}0.114 \\
(0.09)\end{array}$ & $\begin{array}{c}0.041 \\
(0.041)\end{array}$ & $\begin{array}{c}0.043 \\
(0.041)\end{array}$ \\
\hline Age $60-69$ & $\begin{array}{c}-0.109 * * * \\
(0.021)\end{array}$ & $\begin{array}{c}-0.078^{* * *} \\
(0.024)\end{array}$ & $\begin{array}{c}0.009 \\
(0.060)\end{array}$ & $\begin{array}{c}0.086 \\
(0.091)\end{array}$ & $\begin{array}{c}0.158 \\
(0.097)\end{array}$ & $\begin{array}{c}0.113 \\
(0.095)\end{array}$ & $\begin{array}{c}0.052 \\
(0.041)\end{array}$ & $\begin{array}{l}0.064^{*} \\
(0.042)\end{array}$ \\
\hline Age $70-79$ & $\begin{array}{c}-0.123^{* * *} \\
(0.013)\end{array}$ & $\begin{array}{c}-0.099^{* * *} \\
(0.015)\end{array}$ & $\begin{array}{c}0.041 \\
(0.068)\end{array}$ & $\begin{array}{c}0.122 \\
(0.098)\end{array}$ & $\begin{array}{c}0.128 \\
(0.094)\end{array}$ & $\begin{array}{c}0.100 \\
(0.093)\end{array}$ & $\begin{array}{c}0.053 \\
(0.040)\end{array}$ & $\begin{array}{c}0.084^{* *} \\
(0.043)\end{array}$ \\
\hline Single & $\begin{array}{c}0.045^{* *} \\
(0.02)\end{array}$ & $\begin{array}{l}0.033^{*} \\
(0.019)\end{array}$ & $\begin{array}{c}0.016 \\
(0.022)\end{array}$ & $\begin{array}{c}0.007 \\
(0.031)\end{array}$ & $\begin{array}{l}0.023 \\
(0.02)\end{array}$ & $\begin{array}{l}0.027 \\
(0.02)\end{array}$ & $\begin{array}{c}-0.038^{* *} \\
(0.015)\end{array}$ & $\begin{array}{c}-0.030^{* *} \\
(0.015)\end{array}$ \\
\hline Children & $\begin{array}{c}-0.007 \\
(0.008)\end{array}$ & $\begin{array}{l}-0.005 \\
(0.008)\end{array}$ & $\begin{array}{l}0.019^{*} \\
(0.011)\end{array}$ & $\begin{array}{l}0.027^{*} \\
(0.014)\end{array}$ & $\begin{array}{c}0.019 \\
(0.012)\end{array}$ & $\begin{array}{c}0.019 \\
(0.012)\end{array}$ & $\begin{array}{c}0.007 \\
(0.006)\end{array}$ & $\begin{array}{c}0.007 \\
(0.006)\end{array}$ \\
\hline Risk Tolerance 2 & & $\begin{array}{c}0.077^{* * * *} \\
(0.012)\end{array}$ & & $\begin{array}{c}0.044 \\
(0.028)\end{array}$ & & $\begin{array}{c}0.114^{* * *} \\
(0.016)\end{array}$ & & $\begin{array}{c}0.190^{* * *} \\
(0.016)\end{array}$ \\
\hline Risk Tolerance 3 & & $\begin{array}{c}0.222^{* * *} \\
(0.031)\end{array}$ & & $\begin{array}{c}0.090^{* *} \\
(0.042)\end{array}$ & & $\begin{array}{c}0.240^{* * *} \\
(0.027)\end{array}$ & & $\begin{array}{c}0.212^{* * *} \\
(0.034)\end{array}$ \\
\hline Risk Tolerance 4 & & $\begin{array}{c}0.229 * * * \\
(0.062)\end{array}$ & & $\begin{array}{c}0.177^{* * *} * \\
(0.037)\end{array}$ & & $\begin{array}{c}0.509 * * * \\
(0.109)\end{array}$ & & $\begin{array}{c}0.131^{* * *} \\
(0.052)\end{array}$ \\
\hline Risk Tolerance 5 & & & & $\begin{array}{c}0.249^{* * *} \\
(0.048)\end{array}$ & & & & \\
\hline Risk Tolerance 6 & & & & $\begin{array}{c}0.468^{* * *} \\
(0.103)\end{array}$ & & & & \\
\hline Risk Tolerance 7 & & & & $\begin{array}{c}0.303^{* * *} \\
(0.144)\end{array}$ & & & & \\
\hline Pseudo- $\mathrm{R}^{2}$ & 0.26 & 0.30 & 0.10 & 0.17 & 0.13 & 0.17 & 0.32 & 0.36 \\
\hline AIC & 1827 & 1730 & 954 & 815 & 2556 & 2426 & 4327 & 4093 \\
\hline $\mathrm{BIC}$ & 1920 & 1836 & 1034 & 922 & 2651 & 2551 & 4434 & 4220 \\
\hline Number of obs. & 2,556 & 2,556 & 1,091 & 985 & 2,806 & 2,806 & 5,833 & 5,833 \\
\hline
\end{tabular}

To check which econometric model - with the gender variable only or with risk preferences also included - produces a better fit to the data, we compute an AIC (Akaike Information Criterion) and a BIC (Bayesian Information Criterion). The statistics show 
that including risk preferences significantly improves the explanatory power of the model in all four countries.

All in all, in the three countries with relatively high gender equality, investors' gender seems to contain no additional information about risk propensity beyond that already captured in the self-reported risk preferences. In other words, gender has no incremental impact on risk-taking when risk preferences are taken into account. Therefore, in these countries, risk tolerance - even when self-reported - seems to be a better predictor of behavior than gender. Hence, financial advice given to an individual based on the information about his/her risk preference can improve the individual's utility compared to advice based on gender only. In contrast, in Italy - i.e. in the country with the lowest gender equality of those studied - information about an investor's gender can improve the assessment of his/her risk propensity elicited from the self-reported risk tolerance. Following Akerlof and Kranton (2000), we interpret this result as a consequence of the conflict between risk preferences and social identity of men and women in a society with asymmetric gender roles.

\subsection{Effects of gender on the share of wealth allocated to risky assets}

Hypothesis 2 states that, conditional on owning some risky assets, women in countries with a low degree of gender equality hold a lower portfolio share of these assets than men, even if they report equal risk tolerance. The effect of explanatory variables on the share of risky assets is estimated using the Heckman two-stage estimation procedure (Model II). The first-stage regression corresponds to that used in the analysis of the ownership decision (see Table 3). The second-stage regression includes the same explanatory variables as the first-stage regression with two adjustments: wealth enters the second-stage equation as a set of dummies indicating the 1st, 2nd, 3rd and 4th quartiles of the sample distribution; and the dummy variable Real Property is excluded from the equation. This adjustment is necessary in order to enable identification of the model. Coefficient estimates obtained for the second-stage regression are reported in Table 4.

As in the previous table, column (1) contains only socioeconomic and demographic information. In column (2), individual risk tolerance dummies are included. The coefficient on Male in column (1) shows that gender has no statistically significant effect on the portfolio share of risky assets in all countries except Italy. When risk tolerance is taken into account, gender effects in Austria, the Netherlands and Spain remain insignificant and also become insignificant in Italy. Hence, our analysis suggests that there are no differences between men and women with respect to risk-taking in the portfolio allocation decisions once self-reported risk tolerance is controlled for. This evidence rejects Hypothesis 2.

Overall, we find that most of the observable characteristics included have little effect on the allocation decision. Although wealth is found to have negative effect on the share of risky assets in in all four countries, the effect is statistically significant only in the Netherlands. Furthermore, the degree of risk tolerance is positively related to the share of risky assets only in Italy and Austria. Hence, conditional on ownership of risky assets, the decision about what portion of wealth to invest in these assets is driven by unobserved individual-specific effects rather than by the observed socioeconomic characteristics. Weak 
Table 4: Effect of gender on the portfolio share of risky assets (allocation decision)

This table summarizes the results of the estimation of Model II by means of the Heckman two-step procedure. The dependent variable is the portfolio share invested in risky financial assets. The first-stage selection equation (not reported) corresponds to Model I. Columns denoted as (1) report estimation results for the basic specification without the risk tolerance dummies of the first and the second-stage equation. Columns denoted as (2) extend both equations by including variables capturing risk tolerance levels. ${ }^{*}, * *$ and $* * *$ correspond to the $10 \%, 5 \%$ and $1 \%$ significance levels, respectively.

\begin{tabular}{|c|c|c|c|c|c|c|c|c|}
\hline & \multicolumn{2}{|c|}{ Austria } & \multicolumn{2}{|c|}{ Netherlands } & \multicolumn{2}{|c|}{ Italy } & \multicolumn{2}{|c|}{ Spain } \\
\hline & (1) & $(2)$ & (1) & $(2)$ & (1) & $(2)$ & $(1)$ & $(2)$ \\
\hline Male & $\begin{array}{c}0.001 \\
(0.020)\end{array}$ & $\begin{array}{l}-0.009 \\
(0.020)\end{array}$ & $\begin{array}{c}0.098 \\
(0.064)\end{array}$ & $\begin{array}{c}0.049 \\
(0.059)\end{array}$ & $\begin{array}{c}0.093 * * \\
(0.046)\end{array}$ & $\begin{array}{c}0.078 \\
(0.048)\end{array}$ & $\begin{array}{l}-0.007 \\
(0.022)\end{array}$ & $\begin{array}{l}-0.018 \\
(0.022)\end{array}$ \\
\hline $\ln$ (Income) & $\begin{array}{c}0.037 \\
(0.029)\end{array}$ & $\begin{array}{c}0.032 \\
(0.028)\end{array}$ & $\begin{array}{c}0.021^{* *} \\
(0.009)\end{array}$ & $\begin{array}{c}0.017^{*} \\
(0.009)\end{array}$ & $\begin{array}{c}0.108^{* *} \\
(0.047)\end{array}$ & $\begin{array}{c}0.098^{* *} \\
(0.050)\end{array}$ & $\begin{array}{c}0.004 \\
(0.008)\end{array}$ & $\begin{array}{l}-0.003 \\
(0.008)\end{array}$ \\
\hline $\ln$ (Financial Wealth) & $\begin{array}{l}-0.004 \\
(0.012)\end{array}$ & $\begin{array}{l}-0.009 \\
(0.012)\end{array}$ & $\begin{array}{l}-0.013^{*} \\
(0.007)\end{array}$ & $\begin{array}{c}-0.014^{* *} \\
(0.007)\end{array}$ & $\begin{array}{c}-0.012 \\
(0.016)\end{array}$ & $\begin{array}{l}-0.020 \\
(0.016)\end{array}$ & $\begin{array}{l}-0.002 \\
(0.005)\end{array}$ & $\begin{array}{l}-0.003 \\
(0.004)\end{array}$ \\
\hline Self-Employed & $\begin{array}{l}-0.008 \\
(0.017)\end{array}$ & $\begin{array}{l}-0.007 \\
(0.017)\end{array}$ & $\begin{array}{c}0.010 \\
(0.043)\end{array}$ & $\begin{array}{c}0.019 \\
(0.041)\end{array}$ & $\begin{array}{l}0.089^{*} \\
(0.046)\end{array}$ & $\begin{array}{c}0.069 \\
(0.046)\end{array}$ & $\begin{array}{c}0.070 \\
(0.021)\end{array}$ & $\begin{array}{c}0.063 \\
(0.020)\end{array}$ \\
\hline Education & $\begin{array}{c}0.018 \\
(0.041)\end{array}$ & $\begin{array}{c}0.017 \\
(0.041)\end{array}$ & $\begin{array}{l}-0.074 \\
(0.139)\end{array}$ & $\begin{array}{l}-0.150 \\
(0.151)\end{array}$ & $\begin{array}{c}0.198 \\
(0.161)\end{array}$ & $\begin{array}{c}0.116 \\
(0.158)\end{array}$ & $\begin{array}{l}-0.077 \\
(0.085)\end{array}$ & $\begin{array}{l}-0.078 \\
(0.084)\end{array}$ \\
\hline Age $30-39$ & $\begin{array}{l}-0.008 \\
(0.040)\end{array}$ & $\begin{array}{c}-0.004 \\
(0.039)\end{array}$ & $\begin{array}{c}-0.026 \\
(0.139)\end{array}$ & $\begin{array}{l}-0.121 \\
(0.152)\end{array}$ & $\begin{array}{c}0.203 \\
(0.160)\end{array}$ & $\begin{array}{c}0.127 \\
(0.158)\end{array}$ & $\begin{array}{l}-0.032 \\
(0.082)\end{array}$ & $\begin{array}{c}-0.036 \\
(0.081)\end{array}$ \\
\hline Age $40-49$ & $\begin{array}{l}-0.030 \\
(0.042)\end{array}$ & $\begin{array}{l}-0.022 \\
(0.041)\end{array}$ & $\begin{array}{l}-0.047 \\
(0.137)\end{array}$ & $\begin{array}{l}-0.110 \\
(0.152)\end{array}$ & $\begin{array}{c}0.166 \\
(0.157)\end{array}$ & $\begin{array}{c}0.099 \\
(0.155)\end{array}$ & $\begin{array}{c}0.069 \\
(0.081)\end{array}$ & $\begin{array}{c}0.071 \\
(0.081)\end{array}$ \\
\hline Age $50-59$ & $\begin{array}{l}-0.003 \\
(0.048)\end{array}$ & $\begin{array}{c}0.011 \\
(0.047)\end{array}$ & $\begin{array}{l}-0.032 \\
(0.146)\end{array}$ & $\begin{array}{l}-0.131 \\
(0.160)\end{array}$ & $\begin{array}{l}0.283^{*} \\
(0.162)\end{array}$ & $\begin{array}{c}0.211 \\
(0.160)\end{array}$ & $\begin{array}{c}0.052 \\
(0.082)\end{array}$ & $\begin{array}{c}0.055 \\
(0.082)\end{array}$ \\
\hline Age $60-69$ & $\begin{array}{l}-0.022 \\
(0.059)\end{array}$ & $\begin{array}{l}-0.002 \\
(0.057)\end{array}$ & $\begin{array}{l}-0.108 \\
(0.158)\end{array}$ & $\begin{array}{l}-0.154 \\
(0.171)\end{array}$ & $\begin{array}{c}0.168 \\
(0.161)\end{array}$ & $\begin{array}{c}0.123 \\
(0.159)\end{array}$ & $\begin{array}{c}0.100 \\
(0.084)\end{array}$ & $\begin{array}{c}0.112 \\
(0.084)\end{array}$ \\
\hline Age $\geq 70$ & $\begin{array}{c}0.006 \\
(0.030)\end{array}$ & $\begin{array}{c}0.001 \\
(0.030)\end{array}$ & $\begin{array}{l}-0.081 \\
(0.095)\end{array}$ & $\begin{array}{l}-0.145 \\
(0.109)\end{array}$ & $\begin{array}{c}0.013 \\
(0.040)\end{array}$ & $\begin{array}{l}-0.014 \\
(0.042)\end{array}$ & $\begin{array}{c}0.030 \\
(0.024)\end{array}$ & $\begin{array}{c}0.026 \\
(0.024)\end{array}$ \\
\hline Single & $\begin{array}{c}0.051^{* *} \\
(0.023)\end{array}$ & $\begin{array}{l}0.045^{*} \\
(0.023)\end{array}$ & $\begin{array}{l}-0.014 \\
(0.049)\end{array}$ & $\begin{array}{l}-0.033 \\
(0.048)\end{array}$ & $\begin{array}{c}0.029 \\
(0.036)\end{array}$ & $\begin{array}{c}0.038 \\
(0.038)\end{array}$ & $\begin{array}{l}-0.023 \\
(0.024)\end{array}$ & $\begin{array}{l}-0.026 \\
(0.024)\end{array}$ \\
\hline Children & $\begin{array}{l}-0.012 \\
(0.011)\end{array}$ & $\begin{array}{l}-0.010 \\
(0.011)\end{array}$ & $\begin{array}{c}0.007 \\
(0.023)\end{array}$ & $\begin{array}{c}0.012 \\
(0.023)\end{array}$ & $\begin{array}{l}0.041^{*} \\
(0.022)\end{array}$ & $\begin{array}{c}0.040^{*} \\
(0.023)\end{array}$ & $\begin{array}{l}-0.001 \\
(0.011)\end{array}$ & $\begin{array}{c}0.001 \\
(0.011)\end{array}$ \\
\hline Risk Tolerance 2 & & $\begin{array}{c}0.031 \\
(0.024)\end{array}$ & & $\begin{array}{c}0.051 \\
(0.071)\end{array}$ & & $\begin{array}{c}0.200^{* * *} \\
(0.065)\end{array}$ & & $\begin{array}{c}0.069 \\
(0.027)\end{array}$ \\
\hline Risk Tolerance 3 & & $\begin{array}{l}0.056^{*} \\
(0.033)\end{array}$ & & $\begin{array}{l}-0.035 \\
(0.084)\end{array}$ & & $\begin{array}{c}0.379 * * * \\
(0.100)\end{array}$ & & $\begin{array}{c}0.167 \\
(0.039)\end{array}$ \\
\hline Risk Tolerance 4 & & $\begin{array}{c}0.137^{* * *} \\
(0.048)\end{array}$ & & $\begin{array}{c}0.073 \\
(0.082)\end{array}$ & & $\begin{array}{c}0.749 * * * \\
(0.172)\end{array}$ & & $\begin{array}{c}0.181 \\
(0.065)\end{array}$ \\
\hline Risk Tolerance 5 & & & & $\begin{array}{c}0.105 \\
(0.100)\end{array}$ & & & & \\
\hline Risk Tolerance 6 & & & & $\begin{array}{c}0.005 \\
(0.142)\end{array}$ & & & & \\
\hline Risk Tolerance 7 & & & & $\begin{array}{l}-0.087 \\
(0.175)\end{array}$ & & & & \\
\hline Constant & $\begin{array}{l}-0.162 \\
(0.375)\end{array}$ & $\begin{array}{l}-0.098 \\
(0.371)\end{array}$ & $\begin{array}{c}0.090 \\
(0.299)\end{array}$ & $\begin{array}{c}0.232 \\
(0.325)\end{array}$ & $\begin{array}{c}-1.463^{*} \\
(0.794)\end{array}$ & $\begin{array}{l}-1.410 \\
(0.884)\end{array}$ & $\begin{array}{c}0.257 \\
(0.170)\end{array}$ & $\begin{array}{c}0.308 \\
(0.172)\end{array}$ \\
\hline$\lambda$ & $\begin{array}{c}0.036 \\
(0.034)\end{array}$ & $\begin{array}{c}0.037 \\
(0.035)\end{array}$ & $\begin{array}{l}-0.013 \\
(0.097)\end{array}$ & $\begin{array}{l}-0.025 \\
(0.096)\end{array}$ & $\begin{array}{c}0.428^{* * *} \\
(0.116)\end{array}$ & $\begin{array}{c}0.446^{* * *} \\
(0.140)\end{array}$ & $\begin{array}{c}0.062 \\
(0.037)\end{array}$ & $\begin{array}{c}0.064 \\
(0.039)\end{array}$ \\
\hline Total number of obs. & 2,556 & 2,556 & 1,091 & 985 & 2,806 & 2,806 & 5,833 & 5,833 \\
\hline Number of Uncensored Obs. & 463 & 463 & 229 & 212 & 592 & 592 & 1,343 & 1,343 \\
\hline
\end{tabular}

explanatory power of the included variables is not surprising even when they have affected the likelihood of owning risky assets. Not all factors that determine the ownership decision are relevant for the allocation decision. For example, information costs may prevent individuals with low income and low education from participating in the markets for risky financial assets. However, once information is acquired, information costs should not play a role in the allocation decision. 
It should be noted that the results reported in Table 4 also show that the parameter $\lambda$ representing the effect of the correction term (inverse Mills ratio) is only statistically significant for Italy. We find no evidence of correlation between the two stages of the portfolio decision through unobservable factors in Austria, the Netherlands and Spain. The lack of correlation in the three countries means that the two-stage estimation procedure is not necessarily required.

To test the robustness of our results with respect to the choice of the estimation procedure, we additionally estimate the effect of gender on the portfolio share of risky assets using the Tobit estimation procedure. ${ }^{12}$ The results confirm the previous finding: gender does not significantly influence the allocation decision, ceteris paribus. Given that individuals own risky assets, gender cannot serve as a predictor of the share of wealth allocated to these assets. These findings are by and large in line with literature that studies the risk-taking behavior of men and women in specific sub-populations, for example among investment fund managers (Johnson and Powell, 1994; Atkinson et al., 2003; Beckmann and Menkhoff, 2008) or entrepreneurs (Caliendo and Kritikos, 2008). The main finding there is that men and women who self-select into risky activities show similar readiness to actually take risks. What we observe in the household data may reflect a similar selection phenomenon. Within the group of individuals who have already decided to invest in risky assets, men and women do not differ significantly in the decision about the share of risk. As this result holds even for Italy, the country with high gender inequality in social roles and opportunities, it seems to reflect a quite general phenomenon.

\section{Robustness checks}

\subsection{The special case of Italy}

Italy is a particularly interesting case with its outstanding result for the participation decision. In order to further test whether our hypothesis of high gender inequality is responsible for this result, we perform a number of additional estimations specifically for Italy. Firstly, we test whether the effect of gender is specific to particular classes of risk tolerance. To this end, we group the observations into four sub-samples: the first one includes households with the lowest degree of risk tolerance (Risk Tolerance $=1$ ), the second one includes those with Risk Tolerance $=2$; the third sub-sample includes households with Risk Tolerance $=3$ and the fourth sub-sample consists of households with Risk Tolerance $=3$ or 4 . We do not create a specific sub-sample of observations with only Risk Tolerance $=4$ as the size of this group is very small and a regression analysis is not feasible. Then, we estimate Model I by running a probit regression for each of the four sub-samples separately. The estimated marginal effects of the dummy variable Male are reported in Table 5.

According to the results, gender has a significant effect on the probability of holding risky financial assets in the two sub-samples with low risk tolerance. In the sub-samples with higher risk tolerance, men and women are equally likely to invest in risky assets. Thus, the incremental gender effect obtained in the earlier regression, in which risk tolerance groups were pooled together, is driven by the distinct behavior of men and women

\footnotetext{
${ }^{12}$ Results from the Tobit estimation are available from the authors upon request.
} 
Table 5: Effect of gender on the probability of owning risky asset in Italy, by degree of risk tolerance

This table reports the marginal effects of the dummy variable Male on the probability of owning risky financial assets obtained after estimating Model I. Each column reports the results for a sub-sample of households with the specified degree of risk tolerance.

\begin{tabular}{lcccc}
\hline & Risk Tolerance $=1$ & Risk Tolerance $=2$ & Risk Tolerance $=3$ & Risk Tolerance $\geqq 3$ \\
\hline Marg. effect & $0.051^{* * *}$ & $0.095^{* * *}$ & 0.083 & 0.091 \\
St. dev. & $(0.016)$ & $(0.028)$ & $(0.060)$ & $(0.059)$ \\
N obs. & 1378 & 1039 & 362 & 389 \\
\hline
\end{tabular}

with low risk tolerance. This result may imply that, compared to men, the conflict between a decision to hold risky assets and the social identity of a woman is particularly strong within the groups in which taking risks is unpopular anyway.

However, a strong dissonance between action and risk attitudes is not the only that could be responsible for the incremental effect of gender. Strong differences in income could also cause such an effect. In order to evaluate this conjecture, we now focus only on those Italian households who report low risk tolerance (i.e. Risk Tolerance $=1$ or Risk Tolerance $=2$ ). Within this group, we construct four sub-samples of households that belong to different income classes. The first sub-sample includes households whose income falls into the 1st quartile of the sample distribution; the second, third and the fourth sub-samples include those households whose income falls into the 2nd, 3rd and 4th quartiles of the distribution, respectively. Then, Model I is estimated separately for each income class. The results are reported in Table 6 .

Table 6: Effect of gender on the probability of owning risky assets in Italy, by income level (for the sub-sample of households with low risk tolerance)

This table reports the marginal effects of the dummy variable Male on the probability of owning risky financial assets obtained after estimating Model I. Each column reports the results for a sub-sample of households, whose income falls into the specified quartile of income distribution.

\begin{tabular}{lcccc}
\hline & 1st quartile & 2nd quartile & 3rd quartile & 4th quartile \\
\hline Marg. effect & 0.003 & $0.045^{* * *}$ & $0.086^{* * *}$ & $0.077^{* * *}$ \\
St. dev. & $(0.004)$ & $(0.012)$ & $(0.024)$ & $(0.034)$ \\
N obs. & 315 & 520 & 669 & 914 \\
\hline
\end{tabular}

Gender has no effect in the group with the lowest income. This is not surprising, since liquidity constraints prevent both men and women from investing in risky financial assets. Among the households belonging to a higher income class, the effect of gender on the probability of investing in risky financial assets is significant in all three classes. However, the predicted gender differences are largest among the households in the upper two income quartiles. Hence, despite similar financial resources and similar risk propensity, men and women behave differently. This finding rules out income differences as an explanation for the observed incremental effect of gender in Italy and supports the dissonance hypothesis according to Akerlof and Kranton (2000). 


\subsection{The case of single households}

Our main finding is that, in countries with a high degree of gender equality, women and men with the same degree of risk tolerance have equally structured portfolios, ceteris paribus. Therefore, linking financial advice to gender is inappropriate in such countries. This finding differs from the evidence provided by Bajtelsmit et al. (1999) and Jianakoplos and Bernasek (1998), who find significant differences in the structure of portfolios of men and women holding some risky assets. The specifics of the data used in these studies may be responsible for the discrepancy in the evidence. For instance, Bajtelsmit et al. (1999) analyze risk-taking only in the defined contribution pension plans rather than in the entire financial portfolios as we do. The inference of Jianakoplos and Bernasek (1998) relies on the risk-taking behavior of single women only. Yet, we cannot be sure that behavior of single persons is representative of the behavior of all people. Even if we take into account that married women are generally less wealthy than their husbands (Sierminska, Frick, and Grabka (2010)), and hence are on average not much wealthier than single women, a single female might actually be less risk-tolerant than an equally wealthy married female because the latter has an additional safety net in the form of her husband's income and assets.

The differences between singles and those married is less clear for men. On the one hand, single men can be less risk-tolerant than married men as they do not have an additional source of income from their spouses. In this case, gender differences in financial behavior should be less pronounced as single men and women are less risk-tolerant than their married counterparts. On the other hand, if a married man is the sole breadwinner in the family, he may be as risk-tolerant or even less risk-tolerant than a single man who does not have to share the resources. In this case, gender differences will be more pronounced among single people than in the population at large.

To gain clarity about whether our results apply to single persons as well, we analyze next the gender differences in the behavior of single people. The assumption is that being single or not is not influenced by individual risk attitude. The results of the estimations of Model I and II on a sub-sample of singles are shown in Table 7. For brevity, we report only the effects of gender and individual risk attitude. The estimated effects differ from those obtained for the whole population for some but not all countries. For instance, in Austria, the behavior of single persons does not differ from that observed in the population at large. Single women are significantly less likely to hold risky financial assets when risk attitude is not taken into account, while no significant differences exist in the allocation decision. Moreover, men and women are predicted to behave in the same way when risk attitudes are taken into account. In the Netherlands, we find no significant effect of gender on the ownership decision regardless of whether risk attitude is controlled for or not. In contrast, gender is predicted to have a significant effect on the allocation decision. However, this result should be treated with caution as the number of observations used in the test is rather small and can affect the statistical validity of the result. For Italy, we find the same effect of gender on the ownership and allocation decision among single people as in the population at large. Finally, in Spain no significant effect of gender is found with respect to both decisions. All in all, it turns out that gender differences with respect to the ownership and the allocation decision are even less pronounced among singles than in the population at large. 
Table 7: Effect of gender on the probability of owning risky assets: sub-sample of singles

This table shows the results obtained for the sub-sample of singles. Panel I reports marginal effects of gender and risk tolerance levels on the probability of investing in risky assets in the first place. The effects are estimated by probit regression (Model I). Explanatory variables included in the regression but not reported in the table are: ln(Income), wealth quartiles, Real Property, Self-Employed, Education, age group dummies, and Children.

Panel II reports the marginal effects of gender and risk tolerance levels on the portfolio share allocated to risky assets. The effects are estimated by Heckman regression (Model II). Explanatory variables included in the regression but not reported in the table are: $\ln$ (Income), ln(Financial wealth), Self-Employed, Education, age group dummies, and Children.

Columns denoted as (1) report estimation results for the basic specification (without risk tolerance levels), while columns denoted as (2) correspond to the extended specification (with risk tolerance dummy variables). Marginal effects are estimated at country-specific mean values of explanatory variables. $*$, ** and $* * *$ correspond to the $10 \%, 5 \%$ and $1 \%$ significance levels, respectively. Robust standard errors are given in parentheses.

\begin{tabular}{|c|c|c|c|c|c|c|c|c|}
\hline & \multicolumn{2}{|c|}{ Austria } & \multicolumn{2}{|c|}{ Netherlands } & \multicolumn{2}{|c|}{ Italy } & \multicolumn{2}{|c|}{ Spain } \\
\hline & $(1)$ & $(2)$ & $(1)$ & $(2)$ & $(1)$ & $(2)$ & (1) & $(2)$ \\
\hline \multicolumn{9}{|c|}{ Panel I: Participation decision } \\
\hline Male & $\begin{array}{c}0.032^{*} \\
(0.017)\end{array}$ & $\begin{array}{c}0.022 \\
(0.016)\end{array}$ & $\begin{array}{c}0.049 \\
(0.035)\end{array}$ & $\begin{array}{c}0.002 \\
(0.037)\end{array}$ & $\begin{array}{c}0.079^{* * *} \\
(0.015)\end{array}$ & $\begin{array}{c}0.067^{* * *} \\
(0.015)\end{array}$ & $\begin{array}{c}-0.006 \\
(0.013)\end{array}$ & $\begin{array}{l}-0.010 \\
(0.013)\end{array}$ \\
\hline Risk Tolerance 2 & & $\begin{array}{c}0.040^{* * *} \\
(0.152)\end{array}$ & & $\begin{array}{c}0.054 \\
(0.043)\end{array}$ & & $\begin{array}{c}0.114^{* * *} \\
(0.015)\end{array}$ & & $\begin{array}{c}0.117^{* * *} \\
(0.017)\end{array}$ \\
\hline Risk Tolerance 3 & & $\begin{array}{c}0.181^{* * *} \\
(0.211)\end{array}$ & & $\begin{array}{c}0.079 \\
(0.062)\end{array}$ & & $\begin{array}{c}0.239 * * * \\
(0.027)\end{array}$ & & $\begin{array}{c}0.087^{* * *} \\
(0.030)\end{array}$ \\
\hline Risk Tolerance 4 & & $\begin{array}{l}0.078^{*} \\
(0.292)\end{array}$ & & $\begin{array}{c}0.178^{* * *} \\
(0.065)\end{array}$ & & $\begin{array}{c}0.513^{* * *} \\
(0.107)\end{array}$ & & $\begin{array}{c}0.153^{* * *} \\
(0.046)\end{array}$ \\
\hline Risk Tolerance 5 & & & & $\begin{array}{c}0.078 \\
(0.058)\end{array}$ & & & & \\
\hline Risk Tolerance 6 & & & & $\begin{array}{c}0.399^{* * *} \\
(0.142)\end{array}$ & & & & \\
\hline Risk Tolerance 7 & & & & $\begin{array}{c}0.263 \\
(0.231)\end{array}$ & & & & \\
\hline Pseudo- $\mathrm{R}^{2}$ & 0.29 & 0.33 & 0.13 & 0.19 & 0.13 & 0.17 & 0.31 & 0.36 \\
\hline Number of obs. & 974 & 974 & 430 & 373 & 2806 & 2806 & 1881 & 1881 \\
\hline \multicolumn{9}{|c|}{ Panel II: Allocation decision } \\
\hline Male & $\begin{array}{l}-0.015 \\
(0.037)\end{array}$ & $\begin{array}{l}-0.024 \\
(0.037)\end{array}$ & $\begin{array}{c}0.207^{* * *} \\
(0.072)\end{array}$ & $\begin{array}{c}0.146^{* *} \\
(0.070)\end{array}$ & $\begin{array}{c}0.083^{*} \\
(0.043)\end{array}$ & $\begin{array}{c}0.066 \\
(0.045)\end{array}$ & $\begin{array}{c}0.035 \\
(0.041)\end{array}$ & $\begin{array}{c}0.030 \\
(0.042)\end{array}$ \\
\hline Risk Tolerance 2 & & $\begin{array}{c}0.025 \\
(0.054)\end{array}$ & & $\begin{array}{c}0.091 \\
(0.110)\end{array}$ & & $\begin{array}{c}0.203^{* * *} \\
(0.065)\end{array}$ & & $\begin{array}{c}0.034 \\
(0.064)\end{array}$ \\
\hline Risk Tolerance 3 & & $\begin{array}{c}0.045 \\
(0.087)\end{array}$ & & $\begin{array}{l}-0.062 \\
(0.122)\end{array}$ & & $\begin{array}{c}0.383^{* * *} \\
(0.101)\end{array}$ & & $\begin{array}{l}-0.053 \\
(0.096)\end{array}$ \\
\hline Risk Tolerance 4 & & $\begin{array}{c}0.165 \\
(0.113)\end{array}$ & & $\begin{array}{c}0.153 \\
(0.125)\end{array}$ & & $\begin{array}{c}0.762^{* * *} \\
(0.174)\end{array}$ & & $\begin{array}{c}0.091 \\
(0.136)\end{array}$ \\
\hline Risk Tolerance 5 & & & & $\begin{array}{c}0.012 \\
(0.138)\end{array}$ & & & & \\
\hline Risk Tolerance 6 & & & & $\begin{array}{c}0.079 \\
(0.221)\end{array}$ & & & & \\
\hline Risk Tolerance 7 & & & & $\begin{array}{l}-0.044 \\
(0.306)\end{array}$ & & & & \\
\hline$\lambda$ & $\begin{array}{c}-0.037 \\
(0.076)\end{array}$ & $\begin{array}{l}-0.028 \\
(0.082)\end{array}$ & $\begin{array}{c}0.105 \\
(0.139)\end{array}$ & $\begin{array}{c}0.150 \\
(0.155)\end{array}$ & $\begin{array}{c}0.437^{* * *} \\
(0.116)\end{array}$ & $\begin{array}{c}0.453^{* * *} \\
(0.141)\end{array}$ & $\begin{array}{l}-0.000 \\
(0.078)\end{array}$ & $\begin{array}{l}-0.019 \\
(0.085)\end{array}$ \\
\hline Total number of obs. & 974 & 974 & 430 & 373 & 854 & 854 & 1881 & 1881 \\
\hline Number of uncensored obs. & 116 & 116 & 79 & 71 & 132 & 132 & 301 & 301 \\
\hline
\end{tabular}

\subsection{The role of gender in couples' decision making}

The role of gender, like as the role of any individual specific characteristic in couples' financial risk-taking, is a priori not clear. Most likely, it depends on the organization of financial administration within a household. For couples where each partner manages their own earnings separately or where one partner controls the entire household's finances, 
we can with certainty link the decisions to a particular person and investigate the effect of this person's gender on financial risk-taking. However, for couples where the money is managed jointly and both partners have more or less equal influence on the financial decisions, financial risk-taking is probably influenced by both partners. Hence, the gender of one of the partners cannot determine the behavior of the entire couple.

For one of the countries in our data set, we are able to investigate the role of gender in couples with different organization of financial management. The Dutch survey asks two additional questions to the surveyed households that can be used for this kind of analysis (see Table 11 in the Appendix). Based on the answers given by respondents to these questions, we identify two types of couples.

Type 1 Couples: There is a clear division of decision-making on financial matters. Either each member manages his/her own money individually or all the money is pooled together, but only one member manages it or has the most influence on the management. For the former, each member is considered to be the decision-maker with respect to his/her own financial portfolio. For the latter, we identify which household member is the (main) decision-maker. The expectation is that the gender and risk preferences of the decision-makers determine the riskiness of the managed financial portfolios.

Type 2 Couples: These are couples with no clear division of resources or decisionmaking. All money is completely or to a large extent pooled together and both partners decide together how the money is invested. The number of Type 2 couples is 557, which makes $2 / 3$ of all couples in the sample. There is no clear decision-maker in such couples. Therefore, the gender of one of the spouses probably has no effect on the risk-taking of the couple. It is more likely that the degree of risk-taking is affected by the risk preferences of both spouses.

We firstly estimate the effect of gender and risk preferences on the investment decisions (Model I and Model II) taken by couples of Type 1. All the results with respect to the effect of gender on the degree of risk-taking are the same as the results obtained earlier for the entire Dutch sample. In particular, we find that being a man significantly increases the probability of investing in directly held stocks but has no effect on the portfolio share allocated to these assets. Furthermore, the effect of gender on the probability of investing becomes insignificant when investors' risk preferences are taken into account.

Then, we estimate the effect of gender for the couples of Type 2. We have some additional information about the partners that can help us to identify the division of roles in a couple despite the fact that the finances are managed together. Firstly, we have information about which partner is the (self-declared) household head and which is the main earner. Although being simultaneously the household head and the main earner is highly correlated, there is no one-to-one correspondence between the two roles. The proportion of couples with a female household head among the Type- 2 couples is 6.5 $\%$. The proportion of couples having a female main earner is $7.1 \%$. Secondly, we have information about the risk preferences of both couple members. ${ }^{13}$ Since the spouse is also involved in the decision-making, the his/her risk preferences can also have an impact on the riskiness of the portfolio of the entire household.

Thus, we can investigate the role of the gender of the reference person (household head or the main earner), and the role of the risk attitudes of both household members.

\footnotetext{
${ }^{13}$ Unfortunately, not all couples provide information about both partners. Due to the missing information, our sample of couples of Type 2 consists only of 207 observations.
} 
Table 8: Effect of gender on the probability of owning risky assets: sub-sample of couples making the financial decisions jointly

This table shows the results from estimating the likelihood of holding risky assets using a probit regression model. The dependent variable is a binary variable equal to 1 if some directly held stocks are owned and 0 otherwise. The estimated coefficients are reported with the robust standard errors in parentheses. *, ** and *** correspond to the $10 \%, 5 \%$ and $1 \%$ significance levels, respectively.

\begin{tabular}{|c|c|c|c|c|}
\hline \multirow[b]{2}{*}{ Male } & \multicolumn{2}{|c|}{$\begin{array}{c}\text { Reference person: } \\
\text { Household head }\end{array}$} & \multicolumn{2}{|c|}{$\begin{array}{l}\text { Reference person: } \\
\text { Main earner }\end{array}$} \\
\hline & $\begin{array}{c}0.147 \\
(0.359)\end{array}$ & $\begin{array}{c}0.018 \\
(0.507)\end{array}$ & $\begin{array}{c}0.218 \\
(0.336)\end{array}$ & $\begin{array}{c}0.028 \\
(0.406)\end{array}$ \\
\hline Risk Tolerance 2 & & $\begin{array}{c}0.379 \\
(0.356)\end{array}$ & & $\begin{array}{c}0.400 \\
(0.360)\end{array}$ \\
\hline Risk Tolerance 3 & & $\begin{array}{c}0.467 \\
(0.449)\end{array}$ & & $\begin{array}{c}0.504 \\
(0.457)\end{array}$ \\
\hline Risk Tolerance 4 & & $\begin{array}{c}1.328^{* * *} \\
(0.387)\end{array}$ & & $\begin{array}{c}1.330^{* * *} \\
(0.381)\end{array}$ \\
\hline Risk Tolerance 5 & & $\begin{array}{c}2.492^{* * *} \\
(0.508)\end{array}$ & & $\begin{array}{c}2.383^{* * * *} \\
(0.499)\end{array}$ \\
\hline Risk Tolerance 6 & & $\begin{array}{c}2.591^{* * *} \\
(0.869)\end{array}$ & & $\begin{array}{c}3.271^{* * *} \\
(1.116)\end{array}$ \\
\hline Risk Tolerance 7 & & no obs. & & no obs. \\
\hline Diff. Risk Preference & & $\begin{array}{c}-0.215^{* * *} \\
(0.082)\end{array}$ & & $\begin{array}{c}-0.170 * * \\
(0.081)\end{array}$ \\
\hline $\ln ($ Income $)$ & $\begin{array}{c}0.002 \\
(0.036)\end{array}$ & $\begin{array}{c}0.602 \\
(0.375)\end{array}$ & $\begin{array}{l}-0.000 \\
(0.037)\end{array}$ & $\begin{array}{c}0.547 \\
(0.377)\end{array}$ \\
\hline II Wealth quartile & no obs. & no obs. & no obs. & no obs. \\
\hline III Wealth quartile & $\begin{array}{c}0.776^{* * * *} \\
(0.220)\end{array}$ & $\begin{array}{l}0.790^{*} \\
(0.458)\end{array}$ & $\begin{array}{c}0.751^{* * * *} \\
(0.219)\end{array}$ & $\begin{array}{l}0.810^{*} \\
(0.478)\end{array}$ \\
\hline IV Wealth quartile & $\begin{array}{c}1.330^{* * *} \\
(0.236)\end{array}$ & $\begin{array}{c}1.326^{* * * *} \\
(0.476)\end{array}$ & $\begin{array}{c}1.331^{* * *} \\
(0.234)\end{array}$ & $\begin{array}{c}1.394^{* * *} \\
(0.501)\end{array}$ \\
\hline Real Property & $\begin{array}{c}0.161 \\
(0.221)\end{array}$ & $\begin{array}{l}-0.127 \\
(0.316)\end{array}$ & $\begin{array}{c}0.233 \\
(0.228)\end{array}$ & $\begin{array}{l}-0.078 \\
(0.330)\end{array}$ \\
\hline Self-Employed & $\begin{array}{l}-0.528 \\
(0.468)\end{array}$ & $\begin{array}{l}-0.263 \\
(0.640)\end{array}$ & $\begin{array}{l}-0.565 \\
(0.486)\end{array}$ & $\begin{array}{l}-0.724 \\
(0.660)\end{array}$ \\
\hline Education & $\begin{array}{c}0.299 \\
(0.189)\end{array}$ & $\begin{array}{c}0.041 \\
(0.347)\end{array}$ & $\begin{array}{l}0.321^{*} \\
(0.190)\end{array}$ & $\begin{array}{c}0.094 \\
(0.336)\end{array}$ \\
\hline Age 30-39 & $\begin{array}{c}0.807 \\
(0.564)\end{array}$ & $\begin{array}{l}-0.203 \\
(0.668)\end{array}$ & $\begin{array}{c}0.632 \\
(0.573)\end{array}$ & $\begin{array}{l}-0.305 \\
(0.687)\end{array}$ \\
\hline Age $40-49$ & $\begin{array}{c}0.735 \\
(0.561)\end{array}$ & $\begin{array}{l}-0.030 \\
(0.670)\end{array}$ & $\begin{array}{c}0.602 \\
(0.565)\end{array}$ & $\begin{array}{l}-0.108 \\
(0.670)\end{array}$ \\
\hline Age 50-59 & $\begin{array}{c}0.782 \\
(0.530)\end{array}$ & $\begin{array}{l}-0.181 \\
(0.650)\end{array}$ & $\begin{array}{c}0.709 \\
(0.541)\end{array}$ & $\begin{array}{l}-0.112 \\
(0.658)\end{array}$ \\
\hline Age $60-69$ & $\begin{array}{c}0.594 \\
(0.533)\end{array}$ & $\begin{array}{l}-0.260 \\
(0.668)\end{array}$ & $\begin{array}{c}0.488 \\
(0.546)\end{array}$ & $\begin{array}{l}-0.306 \\
(0.669)\end{array}$ \\
\hline Age 70-79 & $\begin{array}{c}0.559 \\
(0.536)\end{array}$ & $\begin{array}{l}-0.077 \\
(0.744)\end{array}$ & $\begin{array}{c}0.470 \\
(0.553)\end{array}$ & $\begin{array}{l}-0.264 \\
(0.757)\end{array}$ \\
\hline Children & $\begin{array}{c}0.143 \\
(0.088)\end{array}$ & $\begin{array}{c}0.057 \\
(0.137)\end{array}$ & $\begin{array}{l}0.162^{*} \\
(0.089)\end{array}$ & $\begin{array}{c}0.065 \\
(0.137)\end{array}$ \\
\hline Constant & $\begin{array}{c}-2.897^{* * *} \\
(0.774)\end{array}$ & $\begin{array}{c}-9.095^{* *} \\
(4.254)\end{array}$ & $\begin{array}{c}-2.909^{* * *} \\
(0.773)\end{array}$ & $\begin{array}{c}-8.553^{* *} \\
(4.280)\end{array}$ \\
\hline $\begin{array}{l}\text { Number of obs. } \\
\text { Pseudo- } R^{2}\end{array}$ & $\begin{array}{l}429 \\
0.12\end{array}$ & $\begin{array}{l}207 \\
0.30\end{array}$ & $\begin{array}{l}421 \\
0.13\end{array}$ & $\begin{array}{l}207 \\
0.31\end{array}$ \\
\hline
\end{tabular}

For this purpose, we estimate our regression model for the participation decision twice. ${ }^{14}$ In the first estimation, the reference person is the household head and we control for the gender of the household head. In the second estimation, the reference person is the

\footnotetext{
${ }^{14}$ The small number of observations prevents us from conducing a regression analysis of the allocation decision.
} 
main earner and we control for the gender of the main earner. In both estimations, we also control for the risk preferences of both partners. Since the risk preferences of the partners in a couple are likely to be correlated, simply including indicators of the level of risk tolerance of the partners may lead to multicollinearity problems. ${ }^{15}$ To avoid this problem, we include a set of dummies indicating the level of risk tolerance of the reference person, and the variable Diff. Risk Preference defined as the difference in the level of risk tolerance between the reference partner and his/her spouse. Higher values of this variable mean that the spouse is more risk averse than the reference person.

The estimation results are reported in Table 8. The central result is that gender does not have an effect regardless of whether risk preferences are taken into account or not and regardless of the definition of the reference person. This finding confirms our expectation that in couples with mutual decision making, the gender of neither of the partners plays a role in the risk-taking. The second important result regards the effect of variables capturing the risk preferences of the reference person and the differences compared with the risk preferences of the spouse. In line with expectations, higher risk tolerance of the reference person is associated with a higher probability of holding risky assets, ceteris paribus. A noteworthy result is the effect of the variable Diff. Risk Preference. In both regressions, this variable has a negative and statistically significant coefficient. This means, firstly, that both the risk preference of the reference person and the risk preference of the spouse have a significant effect on the risk-taking of the couple. Secondly, if the risk preferences of the partners diverge, this results in a compromise with respect to risk-taking. In particular, at any given level of risk tolerance of the reference person, having a more risk-averse spouse reduces the probability that the couple holds risky assets. Therefore, any prediction with respect to financial risk-taking by couples with mutual decision-making must take into account the preferences of both partners. In contrast, the gender of neither the main earner nor of the household head provides any information about the risk-taking propensity of such couples.

\subsection{Extension of the definition of risky assets}

For the reasons mentioned in Section 4.3, narrowing the definition of risky assets to stocks can affect our inference about the role of investors' gender. In this section, we test the sensitivity of the results with respect to the definition of risky assets. The definition is now extended to include both directly held stocks and investments in mutual funds.

The participation rate in total risky assets among the households in our data set is higher than the participation rate in directly held stocks only (see Figure 3 a). This is true for all countries and for both gender groups. However, pronounced differences between the gender groups still remain and are statistically significant. The conditional share of financial portfolios allocated to total risky assets is also higher than the share of directly held stocks (see Figure $3 \mathrm{~b}$ ). Significant gender differences are present only in the Netherlands and in Spain.

To see whether the results of our econometric analysis hold with the extended definition of risky assets, we estimate regressions as described in Section 5. The new dependent variable in Model I is a binary variable equal to 1 if a household has either directly held

\footnotetext{
${ }^{15}$ The coefficient of correlation between the risk preferences of spouses in our sample is $30 \%$ and is statistically significant.
} 
Figure 3: Participation rates and portfolio shares of risky assets (stocks and mutual funds)

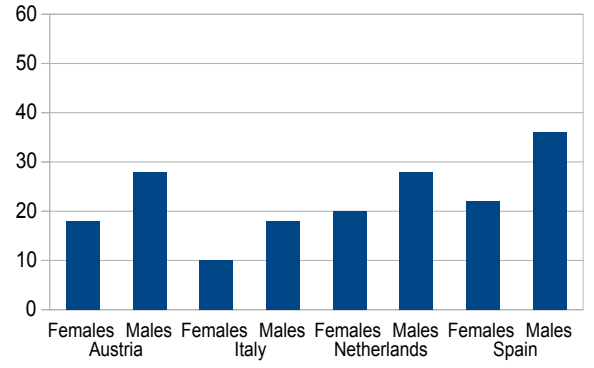

a) Participation rate

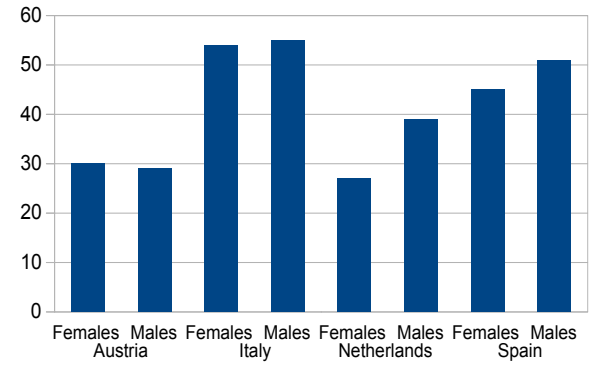

b) Average portfolio share

stocks or investments in mutual funds and 0 otherwise. The new dependent variable in the second stage of Model II is a continuous variable showing the total share of financial wealth invested in directly held stocks and mutual funds. Table 9 reports the estimated effects of gender.

The results are by and large similar to those obtained for the narrow definition of risky assets (i.e. directly held stocks). Specifically, when risk attitudes are not controlled for, females are found to be less likely to invest in total risky assets (i.e. directly held stocks plus mutual funds) than males in all four countries. The differences are statistically significant. When risk attitudes are included, the effect of gender becomes insignificant in all countries except Italy. With respect to the portfolio share of risky assets, when risk attitudes are included, gender seems to have an impact in Italy and - at the $10 \%$ level of significance - in the Netherlands. When risk attitudes are taken into account, gender retains its significant impact only in Italy; however, only at the $10 \%$ level of significance.

In general, the main results are in line with the those obtained for the original definition of a risky asset. Hence, our findings regarding the role of gender in financial risk-taking are robust with respect to the definition of risky assets. 
Table 9: Effect of gender on the probability of owning risky assets (stocks and mutual funds)

This table shows the results obtained for the extended definition of risky assets which includes both directly held stocks and mutual funds. Panel I reports marginal effects of gender on the probability of investing in risky assets. The effects are estimated by probit regression (Model I). Explanatory variables included in the regression but not reported in the table are: In(Income), wealth quartiles, Real Property, Self-Employed, Education, age group dummies, Single and Children. Panel II reports marginal effects of gender on the portfolio share allocated to risky assets. The effects are estimated by Heckman regression (Model $I I$ ). Explanatory variables included in the regression but not reported in the table are: ln(Income), ln(Financial wealth), Self-Employed, Education, age group dummies, Single and Children. Columns denoted as (1) report estimation results for the specification without the risk attitude variables, while columns denoted as (2) correspond to the extended specification with risk attitude variable included. Marginal effects are estimated at countryspecific mean values of explanatory variables. *, ** and *** correspond to the $10 \%, 5 \%$ and $1 \%$ significance levels, respectively. Robust standard errors are given in parentheses.

\begin{tabular}{|c|c|c|c|c|c|c|c|c|}
\hline & \multicolumn{2}{|c|}{ Austria } & \multicolumn{2}{|c|}{ Netherlands } & \multicolumn{2}{|c|}{ Italy } & \multicolumn{2}{|c|}{ Spain } \\
\hline & $(1)$ & $(2)$ & $(1)$ & $(2)$ & (1) & $(2)$ & $(1)$ & $(2)$ \\
\hline \multicolumn{9}{|c|}{ Panel I: Participation decision } \\
\hline Male & $\begin{array}{c}0.052^{* * *} \\
(0.018)\end{array}$ & $\begin{array}{c}0.023 \\
(0.015)\end{array}$ & $\begin{array}{c}0.086^{* * *} \\
(0.032)\end{array}$ & $\begin{array}{c}0.026 \\
(0.038)\end{array}$ & $\begin{array}{c}0.224^{* * *} \\
(0.062)\end{array}$ & $\begin{array}{c}0.085^{* * * *} \\
(0.023)\end{array}$ & $\begin{array}{c}0.034^{* *} \\
(0.014)\end{array}$ & $\begin{array}{c}0.023 \\
(0.014)\end{array}$ \\
\hline Pseudo-R ${ }^{2}$ & 0.27 & 0.30 & 0.18 & 0.26 & 0.15 & 0.19 & 0.32 & 0.35 \\
\hline Number of obs. & 2556 & 974 & 1091 & 985 & 2806 & 2806 & 5962 & 5962 \\
\hline \multicolumn{9}{|c|}{ Panel II: Allocation Decision } \\
\hline Male & -0.003 & -0.025 & $0.109^{*}$ & 0.061 & $0.043^{* *}$ & $0.035^{*}$ & -0.017 & -0.029 \\
\hline & $(0.024)$ & $(0.023)$ & $(0.065)$ & $(0.067)$ & $(0.022)$ & $(0.021)$ & $(0.019)$ & $(0.019)$ \\
\hline$\lambda$ & 0.057 & $0.068^{*}$ & -0.083 & -0.057 & $0.182^{* * *}$ & $0.185^{* * *}$ & -0.018 & -0.020 \\
\hline & $(0.039)$ & $(0.039)$ & $(0.099)$ & $(0.115)$ & $(0.058)$ & $(0.062)$ & $(0.034)$ & $(0.035)$ \\
\hline Total Number of obs. & 2556 & 2556 & 1091 & 1073 & 2806 & 2806 & 5959 & 5959 \\
\hline Number of uncensored obs. & 463 & 463 & 289 & 271 & 1176 & 1176 & 1772 & 1772 \\
\hline
\end{tabular}

\section{Conclusions}

This study investigates the question of whether gender can be considered a good predictor of an individual's readiness to invest in risky assets. Using the national surveys of household finances from four European countries, we show that the difference between men and women in actual risk-taking is most pronounced in Italy - the country with the greatest gender inequality compared to the other three countries. In particular, we find that in Italy women are less likely to invest in risky assets than men, even if they report equal risk tolerance. In contrast, in Austria, the Netherlands and Spain, men and women with equal risk tolerance levels are equally likely to hold risky financial assets in their portfolios. The results for Austria, the Netherlands and Spain, the countries with relatively high degrees of gender equality, reject the hypothesis that actual risk-taking, shown by holdings of risky assets, is a sex-linked trait. In those countries, it is not gender that is a strong predictor for the readiness to invest in risky assets, but rather self-reported risk tolerance.

In none of the four countries does gender play a role in the decision about what portfolio share is allocated to risky assets, once individuals have decided to acquire such assets and self-reported risk tolerance is controlled for. This result confirms previous findings that there is a self-selection effect in actual risk-taking. Men and women who opt to invest in risky assets build portfolios that are similarly structured. Hence, the popular 
belief that the readiness to be exposed to asset risk is a sex-linked trait fails to hold in most instances.

These findings are robust and have important implications for scholars and practitioners. In particular, the results of the study speak against the simplistic approach of using an individual's gender as a predictor for the readiness to invest in risky assets and thus providing gender-specific financial advice. Instead, financial advice should be adjusted to individual risk preferences and abstain from stereotypical beliefs about a "typical" man or woman. The findings also imply that cultural background, and thus the gender equality regime in a country, is linked to the actual risk-taking of men and women. This link will be the avenue for our further research.

\section{References}

Akerlof, G. A. and R. E. Kranton (2000). Economics and identity. The Quarterly Journal of Economics 115(3), 715-753.

Apicella, C. L., A. Dreber, B. Campbell, P. B. Gray, M. Hoffman, and A. C. Little (2008). Testosterone and financial risk preferences. Evolution and Human Behavior 29(6), 384 -390 .

Archer, J. (2006). Testosterone and human aggression: an evaluation of the challenge hypothesis. Neuroscience and Biobehavioral Reviews 30(3), 319 - 345.

Atkinson, S. M., S. B. Baird, and M. B. Frye (2003). Do female mutual fund managers manage differently? Journal of Financial Research 26(1), 1-18.

Bajtelsmit, V. L., A. Bernasek, and N. A. Jianakoplos (1999). Gender differences in defined contribution pension decisions. Financial Services Review 8(1), 1-10.

Beckmann, D. and L. Menkhoff (2008). Will women be women? Analyzing the gender difference among financial experts. Kyklos 61(3), 364-384.

Beer, C., P. Mooslechner, M. Schürz, and K. Wagner (2006). Financial wealth holdings of Austrian private households: Data sources and institutional features. Paper prepared for the Luxembourg Wealth Study Conference 14.

Berger, A. N., T. Kick, and K. Schaeck (2012). Executive board composition and bank risk taking. Discussion Papers 03-2012, Deutsche Bundesbank, Research Centre.

Bernasek, A. and S. Shwiff (2001). Gender, risk, and retirement. Journal of Economic Issues 35(2), 345-356.

Blanco, C., A. Ibánez, C.-R. Blanco-Jerez, E. Baca-Garcia, and J. Sáiz-Ruiz (2001). Plasma testosterone and pathological gambling. Psychiatry Research 105(1-2), 117 121.

Booth, A. and P. Nolen (2012). Choosing to compete: How different are girls and boys? Journal of Economic Behavior \& Organization 81(2), 542-555. 
Bover, O. (2008). The Spanish survey of household finances (EFF): description and methods of the 2005 wave. Banco de España Documentos Ocasionales (0803).

Bröder, A. and N. Hohmann (2003). Variations in risk taking behavior over the menstrual cycle: An improved replication. Evolution and Human Behavior 24(6), 391 - 398.

Caliendo, M. and A. S. Kritikos (2008). Start-ups by the unemployed: Characteristics, survival and direct employment effects. Hanseatic University, Working Paper 008.

Cardenás, J.-C., A. Dreber, E. von Essen, and E. Ranehill (2011). Gender differences in competitiveness and risk taking: Comparing children in Colombia and Sweden. Journal of Economic Behavior and Organization 83(1), 11-23.

Carroll, C. D., B.-K. Rhee, and C. Rhee (1994). Are there cultural effects on saving? Some cross-sectional evidence. The Quarterly Journal of Economics 109(3), 685-699.

Chetty, R. and A. Szeidl (2007). Consumption commitments and risk preferences. The Quarterly Journal of Economics 122(5), 831-877.

Christelis, D., D. Georgarakos, and M. Haliassos (2011). Stockholding: Participation, location, and spillovers. Journal of Banking \& Finance 35(8), 1918-1930.

Coates, J. M., M. Gurnell, and A. Rustichini (2009). Second-to-fourth digit ratio predicts success among high-frequency financial traders. Proceedings of the National Academy of Sciences 106(2), 623-628.

Croson, R. and U. Gneezy (2009). Gender differences in preferences. Journal of Economic Literature $47(2), 448-74$.

Dohmen, T., A. Falk, D. Huffman, U. Sunde, J. Schupp, and G. G. Wagner (2011). Individual risk attitudes: Measurement, determinants, and behavioral consequences. Journal of the European Economic Association 9(3), 522-550.

Eckel, C. C. and P. J. Grossman (2008). Forecasting risk attitudes: An experimental study using actual and forecast gamble choices. Journal of Economic Behavior and Organization 68(1), 1-17.

Faiella, I., R. Gambacorta, S. Iezzi, and A. Neri (2006). Household income and wealth in 2004. Banca d'Italia Supplement to the Statistical Bulletin Nr 7, January.

Fernández, R. and A. Fogli (2006). Fertility: The role of culture and family experience. Journal of the European Economic Association 4(2-3), 552-561.

Finucane, M. L., P. Slovic, C. K. Mertz, J. Flynn, and T. A. Satterfield (2000). Gender, race, and perceived risk: The white male effect. Health, Risk and Society 2(2), 159-172.

Friend, I. and M. E. Blume (1975). The demand for risky assets. American Economic Review 65(5), 900-922.

Giuliano, P. (2007). Living arrangements in Western Europe: Does cultural origin matter? Journal of the European Economic Association 5(5), 927-952. 
Gneezy, U., K. L. Leonard, and J. A. List (2008, January). Gender differences in competition: Evidence from a matrilineal and a patriarchal society. NBER Working Papers 13727, National Bureau of Economic Research, Inc.

Guiso, L., M. Haliassos, and T. Jappelli (2002). Household portfolios. Cambridge, Massachusetts: The MIT Press.

Guiso, L., M. Haliassos, T. Jappelli, and S. Claessens (2003). Household stockholding in Europe: Where do we stand and where do we go? Economic Policy 18(36), 125-170.

Guiso, L., F. Monte, P. Sapienza, and L. Zingales (2008). Culture, gender, and math. Science 320(5880), 1164-1165.

Guiso, L. and P. Sodini (2012). Household finance. An emerging field. EIEF Working Papers Series 1204.

Hackethal, A., M. Haliassos, and T. Jappelli (2012). Financial advisors: A case of babysitters? Journal of Banking \& Finance 36(2), 509-524.

Haliassos, M. and C. C. Bertaut (1995). Why do so few hold stocks? The Economic Journal 105(432), 1110-1129.

Haliassos, M., D. Christelis, and D. Georgarakos (2010). Differences in portfolios across countries: Economic environment versus household characteristics. MEA discussion paper series 10204, University of Mannheim.

Hermans, E. J., P. Putman, J. M. Baas, H. P. Koppeschaar, and J. van Honk (2006). A single administration of testosterone reduces fear-potentiated startle in humans. Biological Psychiatry 59(9), $872-874$.

Jianakoplos, N. A. and A. Bernasek (1998). Are women more risk averse? Economic Inquiry 36(4), 620-30.

Johnson, J. and P. Powell (1994). Decision making, risk and gender: Are managers different? British Journal of Management 5, 123-138.

Lindquist, G. S. and J. Säve-Söderbergh (2011, August). Girls will be girls, especially among boys: Risk-taking in the daily double on jeopardy. Economics Letters 112(2), $158-160$.

Sapienza, P., L. Zingales, and D. Maestripieric (2009). Gender differences in financial risk aversion and career choices are affected by testosterone. Proceedings of the National Academy of Sciences 106, 15268-15273.

Schubert, R., M. Brown, M. Gysler, and H. W. Brachinger (1999). Financial decisionmaking: Are women really more risk-averse? American Economic Review 89(2), 381385 .

Sierminska, E. M., J. R. Frick, and M. M. Grabka (2010). Examining the gender wealth gap. Oxford Economic Papers 62(4), 669-690. 
Stenstrom, E., G. Saad, M. V. Nepomuceno, and Z. Mendenhall (2011). Testosterone and domain-specific risk: Digit ratios (2d:4d and rel2) as predictors of recreational, financial, and social risk-taking behaviors. Personality and Individual Differences 51(4), 412 416.

Van Els, P., J. W. Van den End, and M. Van Rooij (2005). Financial behaviour of Dutch households: analysis of the DNB Household Survey. BIS Papers 22, 21-40. 


\section{Appendix}

Table 10: Survey questions about the attitude toward financial risks

\begin{tabular}{|c|c|}
\hline Country & Survey question \\
\hline Austria & $\begin{array}{l}\text { "For savings I prefer secure investment instruments and avoid risk" } \\
1=\text { completely applicable; } \\
2=\text { rather applicable; } \\
3=\text { rather not applicable; } \\
4=\text { completely inapplicable. }\end{array}$ \\
\hline Netherlands & $\begin{array}{l}\text { Please indicate on a scale from } 1 \text { to } 7 \text { to what extent you agree with the "I am prepared to take the risk } \\
\text { to lose money, when there is also a chance to gain money", where } 1 \text { indicates 'totally disagree' and } 7 \\
\text { indicates 'totally agree'. }\end{array}$ \\
\hline Spain & $\begin{array}{l}\text { "Which of the following statements do you feel best describes your household in terms of the amount of } \\
\text { financial risk you are willing to run when you make an investment?" } \\
\text { 1=Take on a lot of risk in the expectation of obtaining a lot of profit; } \\
2=\text { Take on a reasonable amount of risk in the expectation of obtaining an above-normal profit; } \\
3=\text { Take on a medium level of risk in the expectation of obtaining an average profit; } \\
4=\text { You are not willing to take on financial risk. }\end{array}$ \\
\hline Italy & $\begin{array}{l}\text { "Which of the statements on this page comes closest to the amount of financial risk that you are willing } \\
\text { to take when you save or make investments?" } \\
1=\text { low returns, without any risk of losing your capital; } \\
2=\text { a reasonable return, with a good degree of security for your invested capital; } \\
3=\text { a good return, with reasonable security for your invested capital; } \\
4=\text { very high returns, regardless of a high risk of losing part of your capital. }\end{array}$ \\
\hline
\end{tabular}

Table 11: Questions in the Dutch survey about the organization of financial management of couples

Which of the following four statements would best describe the way in which financial matters are decided in your household?

(1) I leave it to my partner to decide on financial matters.

(2) My partner has more influence than me on financial decisions.

(3) My partner and I have equal influence on financial decisions.

(4) I have more influence on financial decisions than my partner does.

(5) My partner leaves the financial decisions to me.

Now we would like to ask you how your household is organized and how financial decisions are taken. Which of the following statements represents the situation in your household most?

(1) All our money belongs to both of us, there is no distinction between mine and yours.

(2) Part of the money is considered to be someone's own, the other part is mutual money.

(3) The money we earn individually is one's own.

(4) I control the finances, my partner receives an allowance.

(5) My partner controls the finances, I receive an allowance.

(6) I get part of the household money, my partner controls the rest.

(7) My partner receives part of the household money, I control the rest.

(8) Another settlement.

(9) The above is not applicable for my situation/I do not have a partner.

(10) don't know. 